\title{
Disclosure by Politicians
}

\section{Citation}

Djankov, Simeon, Rafael La Porta, Florencio Lopez-de-Silanes, and Andrei Shleifer. 2010. Disclosure by Politicians. American Economic Journal: Applied Economics 2, no. 2: 179-209. doi:10.1257/app.2.2.179.

\section{Published Version}

doi:10.1257/app.2.2.179

\section{Permanent link}

http://nrs.harvard.edu/urn-3:HUL.InstRepos:33077931

\section{Terms of Use}

This article was downloaded from Harvard University's DASH repository, and is made available under the terms and conditions applicable to Open Access Policy Articles, as set forth at http:// nrs.harvard.edu/urn-3:HUL.InstRepos:dash.current.terms-of-use\#OAP

\section{Share Your Story}

The Harvard community has made this article openly available.

Please share how this access benefits you. Submit a story.

Accessibility 
NBER WORKING PAPER SERIES

DISCLOSURE BY POLITICIANS

\author{
Simeon Djankov \\ Rafael La Porta \\ Florencio Lopez-de-Silanes \\ Andrei Shleifer \\ Working Paper 14703 \\ http://www.nber.org/papers/w14703
}

\author{
NATIONAL BUREAU OF ECONOMIC RESEARCH \\ 1050 Massachusetts Avenue \\ Cambridge, MA 02138 \\ February 2009
}

The authors are from the World Bank, Dartmouth College, EDHEC Business School, and Harvard University, respectively. This paper is part of a broader project examining the rules of political disclosure and their consequences. A preliminary report on other data collected for this project is Schneider (2007). This paper would not have been possible without the extensive research by the World Bank team which included: Elena Gasol, Teymour Abdel Aziz, Doina Cebotari, Hania Dawood, Joyce Ibrahim, Stephanie Musialski, Ivana Rossi, and Larisa Smirnova. We also want to thank Christopher Brouwer, Daniel Chen, Nicholas Coleman, William Gaybrick, Wonbin Kang, and Francisco Queiro for help with the project. We would also like to thank William Easterly and Luigi Zingales and participants at the seminars of the Universities of Amsterdam, Brown, EDHEC, Harvard, La Sorbonne, Tilburg, and Toulouse for extremely useful suggestions. Shleifer is grateful to the Kauffman Foundation for the support of this research. The full data set, disclosure blank forms, and a legal appendix for each country can be

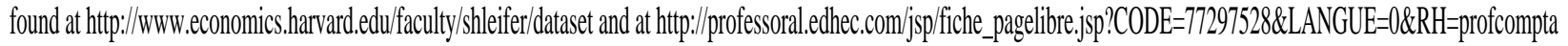
The views expressed herein are those of the author(s) and do not necessarily reflect the views of the National Bureau of Economic Research.

NBER working papers are circulated for discussion and comment purposes. They have not been peerreviewed or been subject to the review by the NBER Board of Directors that accompanies official NBER publications.

(C) 2009 by Simeon Djankov, Rafael La Porta, Florencio Lopez-de-Silanes, and Andrei Shleifer. All rights reserved. Short sections of text, not to exceed two paragraphs, may be quoted without explicit permission provided that full credit, including $\odot$ notice, is given to the source. 
Disclosure by Politicians

Simeon Djankov, Rafael La Porta, Florencio Lopez-de-Silanes, and Andrei Shleifer

NBER Working Paper No. 14703

February 2009

JEL No. H11,K42,P16

\section{ABSTRACT}

We collect data on the rules and practices of financial and conflict disclosure by politicians in 175 countries. Although two thirds of the countries have some disclosure laws, less than a third make disclosures available to the public. Disclosure is more extensive in richer and more democratic countries. Disclosure is correlated with lower perceived corruption when it is public, when it identifies sources of income and conflicts of interest, and when a country is a democracy.

Simeon Djankov

The World Bank

1818 H Street

Washington, DC 20433

sdjankov@worldbank.org

Rafael La Porta

Tuck School

314 Woodbury

Hanover, NH 03755

and NBER

rafael.laporta@dartmouth.edu
Florencio Lopez-de-Silanes

EDHEC Business School

393, Promenade des Anglais BP 3116

06202 Nice Cedex 3, France

and NBER

Florencio.lopezdesilanes@edhec.edu

Andrei Shleifer

Department of Economics

Harvard University

Littauer Center M-9

Cambridge, MA 02138

and NBER

ashleifer@harvard.edu 


\section{Introduction.}

Successful political systems hold politicians accountable for corrupt behavior. The principal mechanisms of such accountability include checks and balances among branches of government, law enforcement, and voting in elections. Political theorists going back to Locke, Montesquieu, and Madison emphasize the centrality of accountability for good government. More recently, the various mechanisms have been investigated by Barro 1973, Ferejohn 1986, Przeworski et al. 2000, Schedler et al. 1999, Persson and Tabellini 2003, Besley and Prat 2006, among others. A number of empirical studies show the benefits of accountability for the quality of government (e.g., Besley and Case 1995, La Porta et al. 1999, Adsera et al. 2003, Eijffinger and Geraats 2005, Olken 2007, Dyck et al. 2008, Ferraz and Finan 2008, Bjorkman and Svensson 2009).

Accountability of government officials for corruption relies on availability of information about their activities. Recent analyses focus on the role of the media as the source of discovery and dissemination of such information to both voters and law enforcement agencies (e.g., Brunetti and Weder 2003, Djankov et al. 2003, Besley and Prat 2006, Reinikka and Svensson 2004). Media surely matter, but there is another, relatively neglected, source of information that facilitates discovery of corruption, namely disclosure by politicians of their finances and business activities. By exposing inconsistencies between the politician's actual conduct and his reports about it, disclosure can influence both reporting in the media (and thus voting) and law enforcement.

There are complex theoretical issues concerning what should be disclosed and how publicly. Disclosure conflicts with privacy, for example, which many regard as a value in itself. Privacy also protects politicians, particularly the well-off ones, from 
populist media coverage or even from robbery or kidnapping. Such protection might, in turn, bring more qualified people into politics. But if the political market is like other markets, then better information about the goods being transacted, such as politicians, improves market performance (see Hirshleifer 1980, Stigler 1980, Posner 1981).

Even if some disclosure is warranted to improve the performance of the political market, the community needs to decide what should be disclosed and to whom. The law can emphasize the disclosure of sources of income and business connections, presumably to deter politicians from supporting legislation from which they benefit personally. Alternatively, the law can emphasize the disclosure of levels of income, consumption, and wealth, presumably to make it easier to identify consumption unaffordable from official resources. Or the politicians may have to disclose both. We do not know empirically whether actual disclosures focus on asset and income levels or on sources, and whether either of these types of disclosure matters for accountability.

Another key question is whether disclosure should be made public. Those concerned with privacy can argue that politicians should disclose to some official office that keeps the information secret unless questions are raised about the politician's conduct that require an investigation. On the other hand, political mechanisms such as media coverage, voting, and investigation are most effective when disclosure is public. Again, it is an empirical question whether confidential or public disclosure works better.

In this paper, we analyze the rules and the practices of disclosure by members of the lower house of parliament or congress (henceforth MPs) in 175 countries. The analysis is based on the laws governing financial and business disclosure of MPs, and on their implementation in practice. We pay attention to 1) the existence of disclosure 
mandates, 2) public availability of disclosures in practice, and 3) the extent of information being disclosed. We collect new data to construct several disclosure indices for all countries and to assess their determinants and their effects on perceived corruption.

We find that, although 109 of 175 countries in our sample have disclosure laws, more than half of them do not make disclosures available to the public in practice. Even in cases of public disclosure, what is available to the public is often limited. Using a new methodology that compares the potential and the actual disclosure, we find that, for the average country with required disclosures, less than 15 percent of potential information about the MPs is actually available to the public. Yet we also find that it is public rather than confidential disclosure that is associated with lower perceived corruption. With respect to the content of disclosure, our evidence shows that identifying the assets, liabilities, income sources, and conflicts is associated with lower perceived corruption. In contrast, we find no significant evidence of benefits from the disclosure of values of income, consumption, and wealth.

We construct indices of disclosure by politicians for 175 countries and assess their relationship to corruption. But why would one think, a priori, that such disclosure matters? We have found recent newspaper accounts of failures to disclose accurately leading to criticism and disciplinary action against MPs in over 20 countries. Some examples illustrate how this works. A Puerto Rican legislator, Nicolas Nogueras, was forced to resign as vice president of the senate because "financial statements he filed in recent years do not explain where he came with the money to make a $\$ 50,000$ down payment for a \$350,000 second home.” The Argentine Economy Minister, Felisa Miceli, resigned after an envelope containing US\$80,000 in cash was found in the private 
bathroom of her office, and she failed to explain where the money came from in light of the asset declaration she had submitted. In South Africa, several prominent politicians, including Winnie Mandela, were caught with assets far in excess of their declarations, and eventually left their parliamentary positions, some landing in jail. In the U.K., two Labour MPs, Mo Mowlam and Bob Wareing, failed to declare outside interests and gave wrong information when challenged. The former was mildly censured, the latter suspended from the Commons. Finally, in 2008 the U.S. saw two major investigations (and in the second case, a criminal conviction) related to a failure to disclose: Democratic Representative Charlie Rangel and Republican Senator Ted Stevens.

In all these examples, financial and conflict of interest disclosure is part of a broader system of accountability that includes media reporting, law enforcement, party discipline, and voting itself. In general, MPs are vulnerable to at least two major sources of undue influence. First, they are sometimes paid directly by heads of government needing their votes with bribes (or perhaps more benignly through appropriations for their constituents). Such direct payments have been alleged in Brazil, Russia, and Argentina, and have been extensively documented in Peru under Fujimori (McMillan and Zoido 2004). Second, MPs may support bills that either benefit themselves or their families directly, or alternatively benefit selected constituents who pay for the bills through bribes or favors (Faccio 2006, Gehlbach et al. 2007). Both kinds of corruption are more easily detected when MPs must disclose their assets because their observed consumption exceeds the declared resources (Di Tella 2007). Voting for bills benefiting the MP or specific constituents can also be more easily detected when business dealings or income sources are disclosed. Once excessive consumption or conflicted voting is 
detected, they can be addressed by law enforcement agencies or exposed in the newspapers, which may sway voters. Disclosure thus sheds light on misconduct by MPs by pointing to discrepancies or outright conflicts.

There is a natural parallel between financial and business disclosure by politicians and that by corporations issuing securities (Grossman and Hart 1980, La Porta et al 2006) or by corporate executives involved in self-dealing transactions (Djankov et al. 2008). In all these instances, disclosure brings the potentially conflicted conduct into light, so that the ultimate decision makers, be they law enforcement officials, shareholders, or voters, can exercise their rights in disciplining misconduct.

We examine the relationship between perceived corruption ${ }^{2}$ and the various channels of accountability, including disclosure, media, and democratic institutions. We face the challenge that disclosure rules are recent. Although some countries had disclosure earlier, modern disclosure practices begin in the 1980s, and the international push toward disclosure by politicians occurs in the last 20 years, as part of a broader wave of democratization. Close to half of the countries in our sample passed disclosure laws in the 1990s. If the effects of disclosure materialize slowly, we might not be able to observe, at the start of the $21^{\text {st }}$ century, their full effect on corruption. ${ }^{3}$

More generally, we do not have enough information to causally interpret the link between disclosure and corruption, in part because there are omitted variables, and in part because corruption itself can shape disclosure legislation. Some obvious instruments such as culture or legal traditions are likely to predict corruption directly and not just

\footnotetext{
${ }^{2}$ In addition to the papers already mentioned, empirical studies of determinants of corruption include Treisman (2000, 2007), Fisman and Gatti (2002), and Svensson (2005).

${ }^{3}$ We have no data on the role of law enforcement in battling corruption. We have made a substantial effort to explore the effects of the introduction of the laws, but do not have enough data to do this properly.
} 
through disclosure. Nonetheless, our paper provides the first evidence as to which aspects of disclosure are correlated with perceived corruption, and as such generates useful hypotheses for future work.

In section II, we describe our data. Section III presents the basic facts about the determinants of disclosure rules around the world. Section IV shows the effects of various institutions, including disclosure, on perceived corruption. Section V concludes.

\section{Data.}

\section{Sample Description}

We present a new database on financial and business disclosure of members of the lower house of parliament (MPs) in 175 countries. $^{4}$ Upper house members, cabinet members, and judges are also frequently required to file disclosure forms, but this paper focuses on MPs in part because other high level officials are often subject to similar disclosure requirements, and in part because MPs are numerous enough that extreme political sensitivity in data collection can be avoided. The data have been assembled by the co-authors and several collaborators over three years.

As a first step, we used the internet as well as contacts with country government agencies, World Bank country offices, UN missions, and local Non-Governmental Organizations and academics to assemble the database of laws governing disclosure by MPs as of June 2008. There is no standard "law" that addresses disclosure, so in the end we assembled (and translated) over 1000 laws and regulations, including constitutions,

\footnotetext{
${ }^{4}$ The distribution of countries in the sample is: 45 from Sub-Saharan Africa; 19 from Middle East and North Africa; 7 from South Asia; 28 from East/Central Europe and Central Asia; 23 from East Asia and Pacific; 30 from Latin America and Caribbean; and 23 from OECD.
} 
parliament standing orders, and anti-corruption and conflict of interest laws. Whenever possible, we contacted multiple sources to verify the accuracy of information.

The analysis of the laws revealed that some kind of disclosure is required of MPs in 109 of our 175 countries, and no disclosure is legally required in the remaining 66 countries (see Table 1). The list of countries with no legally required disclosure is dominated by 27 countries from Sub-Saharan Africa, but also includes 12 from the Middle East and North Africa, and another 11 from East Asia Pacific. In addition to the 109 countries with disclosure requirements, 5 countries have no legal requirement but use voluntary disclosure mechanisms established either by parliamentary rules (Denmark, Finland, and Norway), ${ }^{5}$ internal party regulations (Singapore), or imitation of disclosure by cabinet members (Zambia).

An examination of the laws yielded a crucial observation that became central to our analysis. Specifically, there are large differences among countries in the ability of citizens to access the MPs' disclosure forms. In 46 of the 109 countries mandating disclosure by law, disclosure is made solely to specific government agencies, such as the Speaker of Parliament or an internal Comptroller, but is inaccessible to the public. Most of these countries without public disclosure are from low and middle income groups. Among OECD countries, only France has disclosure without public availability by law. The other 63 countries make some kind of disclosure available to the public by law. In 3 of these countries, disclosure must be made public after application by members of the press. Another 9 countries only make disclosure publicly available under certain conditions, such as the authorization of the Speaker, the Comptroller, or the MP. Finally, 6 countries have different public availability standards for different kinds of disclosure,

\footnotetext{
${ }^{5}$ Until 2007, Sweden, like other Scandinavian countries, did not require disclosures by law.
} 
keeping some disclosures from public access. ${ }^{6}$ Of the 175 sample countries, only 46 mandate that MPs make all required disclosures publicly available without conditions! This is a rather low number if this information is relevant to voting decisions.

As it turns out, even mandating public disclosure by law is no guarantee that the public can obtain this information. To take this into account, we tried to collect the filled out disclosure forms in countries with public disclosure, using the assistance of the World Bank researchers and students in the relevant countries. We tried to obtain the filled out forms of the first four MPs in alphabetical order and of the speaker of the lower house. We made sure that no inappropriate methods were used to obtain the forms. We were able to obtain the actual filled-out disclosure forms in 55 countries. In 50 of these cases disclosures are publicly available by law, in one case (Bahrain) we obtained the forms even though public disclosure is not mandatory, and in another 4 cases there is a voluntary system of disclosure in place without legal mandates. We obtained the filledout forms either through the internet, or through one or multiple appearances at the relevant government office. ${ }^{7}$ We failed to obtain the filled-out forms in 13 countries. These include countries where forms must be publicly available by law (Algeria, Angola, Namibia, Peru, Sri Lanka, and Uganda), with specific conditions (Bahamas, Belize, Cape Verde, Kazakhstan, Mexico and Nicaragua), or via the press (Russia). The central distinction we measure is that between any legal disclosure requirement and disclosures actually available to the public. We have also constructed measures of public disclosure according to the law, as opposed to in practice, but as we show they are not what matters.

\footnotetext{
${ }^{6}$ South Korea is included in this group because the law does not specify the public availability of conflicts of interest's disclosures. In practice, we were able to access all disclosures for South Korean MPs.

${ }^{7}$ In 4 countries (Italy, Japan, Luxembourg, and Spain), we could not photocopy the forms but could copy information by hand.
} 
As a second aspect of measuring disclosure, we consider its content and comprehensiveness. Even among the countries that mandate public disclosure, the actual disclosure available to the public is often far less complete than that available to government agencies. To get at the content, we sought to obtain the blank forms that MPs are asked to fill out from all countries with legally required disclosures or with voluntary disclosure systems. We obtained such blank forms from 106 countries, including 101 with legally required disclosures and another 5 with voluntary disclosure systems in place. We failed to obtain blank forms in eight countries. ${ }^{8}$ For the countries where public disclosure is more limited than that to congress, we collected both types of forms. We then used the blank and filled-out disclosure forms to construct indices of completeness of disclosure relative to the benchmark of a "universal" disclosure form that contains all the disclosures used in any of sample countries. We thus have information not only about the broad mandates required by the law, but also about the extent of actual disclosure when the MPs fill out the forms.

\section{Disclosure Variables}

Based on the information-gathering strategies described above, we construct eight disclosure variables. These and other variables used in the analysis are defined in Table 2. Summary statistics are presented in Table 3.

The first group includes two indicators that do not rely on the content of disclosures. The first records whether any disclosure is required from MPs. As Table 3 shows, 62 percent of countries in our sample require some kind of disclosure from MPs

\footnotetext{
${ }^{8}$ In Angola and Togo there is a "free form" system in place, in Morocco and Swaziland the form does not exist, in Papua New Guinea we were told the form is confidential, and we have not been able to confirm if the form exists in Comoros, Sao Tome and Principe, and the Solomon Islands.
} 
and these disclosures are always available to congress or another specified body. Highand upper-middle income countries are more likely to require disclosures, while only 35 percent of low income nations have MP disclosure requirements. The second variable in Table 3 records whether disclosure is actually available to the public, i.e., citizens have access to the completed forms in practice. In our sample, disclosure is publicly available by law or under certain conditions in 63 countries but publicly available in practice in 55 countries, including the four countries with voluntary disclosures mentioned above (see Table 1). Less than a third of the total sample has genuine public disclosure.

The second group of variables deals with the content of disclosure. Roughly speaking, we ask what share of "conceivable" disclosures are actually made by MPs. For these content variables, we construct a measure of what is available to congress ${ }^{9}$ (based on the blank forms) and a measure of what is actually available to the public (based on the filled out forms we obtained). ${ }^{10}$ We assume that MPs disclose what they are asked to disclose on the blank form, but not more. We use the blank disclosure forms collected from 106 countries to construct an artificial universal disclosure form that incorporates all information that any country requires its MPs to disclose. For each country, we keep track of which of these "universal form" items are disclosed to congress or to the public. When there is an ambiguity as to what a particular disclosure request calls for (i.e., Does a request to disclose share ownership cover mutual funds?), we assume that the form intends broader disclosure (i.e., yes, it does), thus raising national content scores.

\footnotetext{
9 Throughout the paper, we refer to "disclosures to congress," as a shortcut for disclosures available either congress or any other entity that serves as the registry for the disclosures of MPs, even if this entity independent from congress.

${ }^{10}$ In many countries, MPs need to fill in more than one form either at the beginning of their job, during their work and at the end of their terms (e.g., financial interests, conflicts of interest, gifts, and travel forms). All of these forms were considered as part of their disclosures.
} 
The "universal form" covers items in the following seven areas: (1) assets (e.g. real estate, vehicles, bank accounts, stocks, and business ownership); (2) liabilities (e.g., mortgages, loans); (3) expenditures (e.g., home expenses, education, health, taxes); (4) income (e.g., from public and private employers, independent activities, businesses, financial gains, other sources such as gambling); (5) potential conflicts of interest (e.g., unpaid advisory work or board memberships, participation in associations and nonprofits, post-tenure agreements); (6) gifts; and (7) travel.

Some countries restrict business activities of the MPs, their ability to receive gifts, or to own assets. Such restrictions can substitute for disclosure. The universal form allows us to account for such restrictions. Whenever there is a restriction that is binding in a given item, we code the restriction as the highest disclosure standard.

MPs may need to make two types of disclosure of items in these seven areas: (1) the values of their assets, liabilities, expenses, income, gifts, and travel, and (2) information needed to identify assets, liabilities, the sources of income, gifts and travel, and parties with whom they have relationships or associations. We refer to these two types of disclosure as values and sources, recognizing that "sources" is a somewhat loose reference encompassing all matters of identification of assets or activities. In our coding, for each of the areas, the index of values equals 0 if no disclosure is required, 0.5 if only aggregate values need to be disclosed (e.g., total wages, total real estate), and 1 if itemized values need to be disclosed. Similarly, for each of the areas, the index of sources equals 1 if items need to be identified precisely and 0 otherwise. ${ }^{11}$ We measure the indices of values and sources separately for what is available to congress and to the public. These data are shown in the four columns under "form content" in Table 3.

11 “Conflicts of interest” have no values. Likewise, “expenditures” only have values, not sources. 
Measures based on the universal form can take into account the extent of disclosure not only by the MP, but also by family members. We do not present results with family members, although our findings are robust to their inclusion. ${ }^{12}$

In sum, we have four disclosure content variables, based on what goes to congress and to the public, and dividing disclosures into values and sources. The Canadian blank form illustrates the components of the "universal form." Canada has different disclosure standards for congress and the public. We start by describing the blank form available to congress. As explained above, there are seven areas of disclosures required from MPs. The first area is assets. In Canada, MPs must fill out all the details (i.e., address, estimated value, description, purpose, co-owners) about their personal residence and other real property (i.e., buildings, farms, land, and property investments). The blank form also asks about the details and the values of business assets, as well as financial investments and securities (i.e., stocks, bonds, funds, options, insurance policies, savings plans, retirement accounts). However, Canada only requires MPs to disclose an aggregate value for term deposits and other interest-bearing financial instruments, which would not allow the reader to know their individual values or their location. Moreover, unlike many countries, Canada does not require the disclosure of movable assets, such as vehicles, jewelry, or art. Overall, Canada gets a values (sources) disclosure to congress score of $0.58(0.67)$ in the category of assets.

Liabilities are the second category of disclosure. Here the Canadian blank form requires all the information to identify individual debts or liabilities, mortgages, and guarantees in amounts over 10,000 Canadian dollars. The form requests the amount of

${ }^{12}$ In our data, 73 of the 106 countries with blank form required the disclosure of all or some items for the family members of the MP. All the analysis and regressions of the paper have also been conducted for indexes that average the content of both the MP form and the MP's family form. Results do not change. 
each obligation and the name of the creditor or lending institution. This information gives Canada a score of 1.0 for the disclosure of both values and sources of liabilities.

The third area of disclosure is expenditures. In Canada, as in the majority of countries in our sample, MPs are not required to detail their expenditure patterns, so Canada gets the minimum score of 0 for values in the expenditure area. ${ }^{13}$

The fourth area of disclosures is income. In Canada, the blank form asks the MP to check from a list of possible sources of income and benefits beyond the parliamentary compensation (i.e., businesses, farms, jobs, partnerships, professions, offices and directorships, contracts, royalties, interest, dividends, rents, trusts, pensions, annuities, disability benefits). In each case, the MP needs to identify the exact source and nature as well as the amount received in the past and the coming year. Canada gets a score of 1.0 for the disclosure of both values and sources of income.

Potential conflicts of interest are also addressed prominently in the Canadian blank form, as it requests that the MP identify his activities and involvements in paid and unpaid contractual or employment relationships, professions, businesses, directorships and management positions in corporations, associations, trade unions and non-profit organizations. The name of the organization and the MP's position must be provided in each case. He must also report his positions and incomes for the following 12 months. Canada has a score of 1.0 in the sources of conflicts of interest reported to congress.

The last two areas covered by the universal form are travel and gifts. Canadian MPs must file a form for each sponsored trip they undertake. In this form, they provide

\footnotetext{
13 Only 13 countries with available disclosure forms actually require expenditure disclosure. Only El Salvador, Georgia, Honduras, Indonesia, Italy, and Ukraine have disclosure levels that give them a score above 0.20 in this area.
} 
the destination, dates, purpose, sponsors, accompanying passengers, and the description and value of gifts received, with supporting documents. Canada gets a score of 1.0 in the areas of values and sources of travel. Finally, Canadian MPs also have to file an additional form for each individual gift or benefit received, stating the nature, the source, and the circumstances. Although we would know the specific value of gifts obtained during a trip, there is no general requirement to provide the individual value of each gift, so Canada scores 0.0 for the disclosure of gift values and 1.0 for gift sources. ${ }^{14}$

The average of the six indices of the areas of disclosures with values gives Canada a total score of values to congress of 0.76. A similar calculation for the six indices of the areas of disclosure with sources gives Canada a score of 0.94. Not all countries disclose as much as Canada. The mean score over 175 countries for values available to congress is 0.22 . If we only consider the 106 countries with available blank forms, this mean rises to 0.34. At the top are Canada, Costa Rica, Jamaica, Georgia, Israel, Indonesia, Namibia, Puerto Rico, and St. Lu cia, with scores above 0.65. The mean score for sources available to congress is 0.29 over all countries and 0.45 over countries with an available blank form. At the top are Australia, Canada, Israel, Namibia, Puerto Rico, Poland, the United Kingdom, and the United States, with scores above 0.80 .

Canada and another 25 countries only make a subset of disclosures available to the public. The "summary" blank forms and the filled-out disclosure forms allow us to compute sources and values indices for disclosures available to the public, and not just to congress. The Canadian values and sources disclosure scores fall to 0.33 and 0.92 . The

${ }^{14}$ Canadian gift policy is an example of binding restrictions. The disclosure of gifts described above refers only to gifts which are considered to be an expression of courtesy or protocol. Canadian MPs are prohibited from any other kind of gifts. Because we code restrictions as the highest disclosure standard, Canada gets a full score of 1 in both values and sources of gifts. 
main cause of this reduction is the suppression of the main details of the addresses of properties, and of the individual values of assets, liabilities and incomes. Public disclosure in Canada still contains information that allows identification of accounts, assets, sources of income, and business connections. The individual forms for gifts and travel are also publicly available in full. Canada still ranks among the top ten countries in content of disclosures publicly-available.

Columns 5 and 6 in Table 3 present the indices for values and sources publiclyavailable in practice. These two columns are our most comprehensive summary measures of the content of MP disclosures, as they consider not only the breadth of the content of the forms, but also the failure of some countries to comply with their public disclosure laws and the availability of data in other countries despite the absence of legal mandates. In the full sample of 175 countries, the mean public disclosure score is 0.09 for values and 0.15 for sources. If we focus on the countries for which we have a blank form, the mean public disclosure score is 0.14 for values and 0.24 for sources. Transparency is quite scarce once we take both the completeness and the actual public availability of disclosures into account.

The last two variables presented in Table 3 concern enforcement of disclosure. The first is the index of the strength of the registrar, the body that collects disclosures. This index reflects three dimensions: whether the registrar is independent from parliament, whether it publishes compliance data, and whether it can penalize MPs for failure to disclose. The second enforcement measure is the index of the strength of the administrative unit which checks the accuracy of disclosure, which might be different from the registrar. The index again aggregates information on whether this unit is 
independent from parliament, whether it publishes the results of verification of accuracy of disclosure, and whether it can penalize MPs for inaccurate disclosure. The strength of the registrar and the checking units are 0.32 and 0.21 for the full sample. For the group of countries with available blank forms, the mean scores for the strength of the registrar and checking units are higher reaching 0.50 and 0.34 respectively.

\section{Determinants of Disclosure.}

Table 3 also presents average scores of disclosure variables grouped by income. Across our measures, high and upper middle income countries generally have the highest disclosure scores and low income countries the lowest. Moreover, although disclosures of values and sources are positively correlated as illustrated in Figures 1 and 2, high income countries stress the disclosure of sources over that of values. Public disclosure of sources is the highest in rich countries (0.32) and declines monotonically with income. The corresponding values disclosure for high income countries (0.09) identical to the world mean. Another finding is that enforcement variables are the highest in upper middle income countries.

Table 4 examines the potential determinants of the six disclosure and two enforcement measures more systematically. We report OLS regressions but have confirmed our results using probits. We always include per capita income as an explanatory variable. One might worry that income is endogenous, so we have also run all the regressions with latitude, yielding very similar results. We also include the average democracy score over 1975-2006 from Polity IV, on the theory that disclosure is more likely in democracies. In Panel A, we include one cultural variable that is often 
significant in the studies of public institutions, namely the percentage of population that is protestant (see, e.g., La Porta et al. 1999). In Panel B, we alternatively add another common predictor of institutional arrangements (including transparency in the corporate sector), namely the legal origin of the country's commercial laws (La Porta et al. 2008). We have also experimented with ethnic fractionalization, which has been shown to influence the quality of government (see, e.g., Easterly and Levine 1997, Alesina et al. 2003), but it is never significant and so is omitted.

The results in Table 4 confirm that economic development is associated with greater disclosure. This is especially true for measures of disclosure to the public, as opposed to merely to congress. A plausible interpretation of this finding is that richer (or higher human capital) countries demand greater accountability of their politicians, and to this end impose more stringent disclosure rules to promote such accountability. There is no evidence that enforcement measures are higher in richer countries.

An even stronger finding in Table 4 is that, for every single measure of disclosure, including enforcement, democratic countries have higher scores, even holding per capita income constant. A plausible interpretation, again, is that disclosure is needed for political accountability, which works through the democratic process.

The results on cultural and legal variables are mixed. Percentage protestant is generally associated with lower disclosure requirements, less disclosure of values and sources to congress, and fewer enforcement powers, but with more publicly available disclosure of sources of assets and conflicts. French civil law countries are similar to common law countries in their disclosure scores. German and Scandinavian civil law countries have greater emphasis on public availability of disclosure than do the common 
law countries, but only German law countries have statistically higher content of values and sources publicly available than common law ones. Partly as a result of the voluntary nature of disclosure in most Scandinavian countries, they show statistically lower indices of the strength of both the registrar and checking units than do common law countries.

The bottom line so far is that per capita income and especially democracy are the strongest correlates of disclosure. We can alternatively ask: what determines the difference between public disclosure and disclosure to congress, which we refer to as "the wedge"? In Table 5, we use the difference between disclosures to public and to congress as dependent variables, and restrict attention to the subsample with some required disclosure. As in Table 4, we use economic development, democracy, percentage protestant, and legal origins as explanatory variables. Per capita income is a statistically significant predictor of the wedge. Democracy enters negatively, but insignificantly, for public availability, values and sources disclosure. German and Scandinavian law countries have relatively more public disclosure than others. The next question is which, if any, of these aspects of disclosure are related to perceived corruption.

\section{Consequences of Disclosure for Perceived Corruption.}

To investigate the effect of disclosure on corruption, we focus on the average over 2003-2007 corruption score from the International Country Risk Guide, a standard measure of perceived corruption with the largest span of country-years. We look at key disclosure variables, and usually control for the log of income per capita in 2006. ${ }^{15}$

\footnotetext{
${ }^{15}$ The results do not change if we control for our enforcement measures. The results are also similar if we use lagged per capita income or latitude. We have also added ethnic fractionalization (Alesina et al 2003) to the specification, but it is never significant and is not used.
} 
Disclosure by politicians is part of a broader framework of accountability, which also includes the political system, media, and law enforcement. Accordingly, in addition to considering disclosure by itself as a determinant of corruption, we also examine its consequences in conjunction with other measures of governance. These fall into three groups. First, we consider democracy and its types, including (1) average democracy over 1975-2006, introduced earlier, (2) proportional representation, and (3) partyspecific, as opposed to candidate-specific, voting. Previous research shows that democracy and proportional representation are associated with lower corruption (Persson and Tabellini 2003). Party-specific voting may deter corruption because parties bear the costs of corruption by their members, and so might discipline them on their own.

Second, in most research in this area, media play a crucial role. We consider three indicators of potential media effectiveness in deterring corruption. The first two are government ownership of the press and of television, respectively, both of which may undermine media's effectiveness in exposing corruption (Djankov et al. 2003). The third indicator is the logarithm of daily newspaper circulation per thousand inhabitants, which in theory should improve media's effectiveness.

Third, again in most theories, the judiciary plays an important role in promoting the accountability of politicians. Our measure of the power of the judiciary is judicial independence from La Porta et al. (2004), which is presumably helpful in making sure that judges can fight corruption without fear of retribution.

Table 6 presents the results for two indicators of disclosure: to congress and to the public. Table 7 then shows the results for the content of public disclosure for both values and for sources. Tables 8 and 9 present some findings separately for democratic and non- 
democratic countries. Tables 10 and 11 examine the robustness of the results to alternative measure of corruption and additional controls.

Before turning to the results on disclosure, Panel A of Table 6 presents the regressions of corruption on measures of governance other than the disclosure variables, such as democracy, media, and judicial independence. All these measures of governance influence corruption. Countries that are more democratic, have proportional representation, party-specific voting, low government ownership of the press and television, and independent judiciaries are all perceived to be less corrupt. These are old results, and they raise the question of whether disclosure by politicians also matters.

In panel B, we add the disclosure requirement dummy (disclosure to congress) to the specifications in Panel A. In most of these specifications, the existence of the disclosure requirement by MPs is associated with higher, not lower, perceived corruption, although the results are only marginally significant. Only two other governance variables (democracy and judicial independence) are significant; the most important (and wellknown) influence on perceived corruption is per capita income (Treisman 2007).

The results are radically different for public disclosure, as illustrated in Panel C. This variable is a statistically significant predictor of lower perceived corruption in every specification, even holding per capita income constant and controlling for other measures of governance. Parameter estimates suggest that introducing public disclosure in practice raises the ICRG corruption score over a third of a standard deviation (which is 1.14). Only democracy and judicial independence retain statistical significance once public disclosure is used as an explanatory variable; media variables lose their significance. Per capita income remains significant in all specifications. 
Table 7 focuses only on public disclosure, but distinguishes between values and sources. ${ }^{16} \quad$ As Panel A shows, public disclosure of values is never statistically significantly associated with perceived corruption. In contrast, as we see in Panel B, greater public disclosure of sources by MPs is statistically significantly associated with lower perceived corruption in every specification. Going from no to complete public disclosure of sources raises the ICRG score by about a standard deviation.

Tables 8 and 9 consider the public disclosure indicator and public disclosure of sources, but divide countries into those with above and below mean average democracy scores. Both of these public disclosure variables are consistently correlated with perceived corruption in democratic, but not in the undemocratic countries (Figures 3 and 4). This evidence is supportive of the idea that transparency matters in so far as it influences accountability. We have run similar regressions dividing countries into those above and below the mean income per capita, and found that the benefits of public disclosure are concentrated in the richer countries.

Table 10 presents the results for alternative measures of corruption using the public disclosure indicator and public disclosure of sources as alternative independent variables. Panel A presents the results for the whole sample, Panel B for democracies. We consider five additional corruption measures: from Kaufmann et al. (2008), Transparency International, the Heritage Foundation, the Global Competitiveness Report, and for a few countries the percentage of firms reporting bribes from the World Bank Enterprise Surveys. These variables are defined in Table 2.

\footnotetext{
${ }^{16}$ Disclosure of either sources or values to congress or to the public by law is uncorrelated with perceived corruption in similar regressions. The enforcement variables come in significant, but with the "wrong" sign: greater strength of registrar and checking unit is related to higher perceived corruption.
} 
In the full sample, the public disclosure indicator does not predict other measures of corruption, while the public disclosure of sources predicts Kauffman et al. and Transparency International measures, but not the others. For the democratic sub-sample, however, both the public indicator and the public disclosure of sources are statistically significant for all but the Enterprise Survey measures. Our indicators of disclosure are significant in seven of the 10 specifications. As in Tables 8 and 9, neither indicator is significant in the low democracy sub-sample. In Table 11, we consider the robustness of these findings to the inclusion of percentage protestant, which has been shown in earlier work to influence corruption (La Porta et al. 1999). Percentage protestant is highly predictive of lower corruption. The results for the two measures of public disclosure become weaker, but they remain significant in ten of the twelve specifications for the democratic sub-sample shown in Panel B.

\section{Conclusion.}

We present new measures of disclosure by MPs in 175 countries, and examine their determinants and influences on perceived corruption. The measures distinguish between public and non-public disclosure and between more and less comprehensive disclosure. These distinctions motivate the creation of several indices of disclosure.

Several findings emerge. First, there is tremendous variation among countries and even among countries with some disclosure mandates - in whether disclosure is made public and how much is made public. Only a third of the 175 countries allow public access to disclosure by politicians. 
Second, perhaps the crucial imperative for political accountability is that disclosure be made publicly. Many countries keep disclosure by MPs in congress, and such secret disclosure, even if extensive, is uncorrelated with perceived corruption. In contrast, public disclosure is associated with lower perceived corruption even controlling for other measures of governance, such as media freedom and democracy. The privacy of politicians may have benefits, but those may come at a cost of higher corruption.

Third, with respect to the content of disclosure, what matters most is identification of sources of an MP's assets, gifts, and activities, rather than the reporting of values of assets and income. This result is perhaps unsurprising once we recognize that disclosure of sources is crucial for detecting conflicts of interest.

Fourth, public disclosure is strongly associated with lower corruption in the democratic but not the undemocratic countries, which points to complementarity of transparency and democratic governance.

Our data do not allow for a causal interpretation of this evidence. Public disclosure by MPs may reduce corruption, or, alternatively, legislatures in corrupt countries may successfully protect themselves against disclosure, particularly public disclosure of conflicts. But this endogeneity concern only reinforces our message as to what might possibly work in reducing corruption; after all, there is surely a good reason why MPs wish to keep disclosures private. And the message is this: If a country, especially a democracy, wishes to pass disclosure laws with the aim of reducing corruption, the most effective laws are those that make disclosure public, and that focus on the sources of the MP's assets and activities, rather than on values. Secret disclosure, in contrast, does not do much for political accountability. 


\section{References}

Adsera, Alicia, Carles Boix, and Mark Paine. 2003. "Are you being served? Political accountability and quality of government," Journal of Law, Economics, \& Organization 19(2): 445-490.

Alesina, Alberto, Devleeschauwer, Arnaud, Easterly, William, Kurlat, Sergio, and Wacziarg, Romain. 2003. "Fractionalization,” Journal of Economic Growth 8(2): 155-194.

Barro, Robert. 1973. "The control of politicians: An economic model," Public Choice 14(1): 19-42.

Beck, Thorsten, George Clarke, Alberto Groff, Philip Keefer, and Patrick Walsh. 2001. "New tools in comparative political economy: The Database of political institutions," World Bank Economic Review 15(1): 165-176.

Besley, Timothy and Anne Case. 1995. "Does electoral accountability affect economic policy choices? Evidence from gubernatorial term limits,” Quarterly Journal of Economics 110(3):769-98.

Besley, Timothy and Andrea Prat. 2006. "Handcuffs for the grabbing hand? Media capture and government accountability,” American Economic Review 96(3): 720-736.

Bjorkman, Martina and Jakob Svensson. 2009. "Power to the people: Evidence from a randomized field experiment of a community-based monitoring project in Uganda," Quarterly Journal of Economics, forthcoming.

Brunetti, Aymo and Beatrice Weder. 2003. "A free press is bad news for corruption," Journal of Public Economics 87(7-8): 1801-1824.

Central Intelligence Agency. CIA World Factbook, published online.

Di Tella, Rafael. 2007. "Choosing agents and monitoring consumption: A note on wealth as a corruption-controlling device,” NBER Working Paper 13163.

Djankov, Simeon, Caralee McLiesh, Tatiana Nenova, and Andrei Shleifer. 2003. "Who owns the media?” Journal of Law and Economics, 46(2): 341-81.

Djankov, Simeon, Rafael La Porta, Florencio Lopez-de-Silanes, and Andrei Shleifer. 2008. "The law and economics of self-dealing," Journal of Financial Economics 88(3): 430-465.

Dyck, Alex, David Moss, and Luigi Zingales. 2008. "Media versus special interests," Mimeo, University of Chicago. 
Easterly, William and Ross Levine. 1997. "Africa's growth tragedy: policies and ethnic divisions," Quarterly Journal of Economics 112(4): 1203-1250.

Eijffinger, Sylvester and Petra Geraats. 2005. "How transparent are central banks?" European Journal of Political Economy, 22(1): 1-21.

Faccio, Mara. 2006. “Politically connected firms,” American Economic Review 369-386.

Ferejohn, John. 1986. "Incumbent performance and electoral control," Public Choice 50(1-3), 5-25.

Ferraz, Claudio and Frederico Finan. 2008. "Exposing corrupt politicians: The Effects of Brazil's publicly released audits on electoral outcomes," Quarterly Journal of Economics 123(2): 703-746.

Fisman, Raymond and Roberta Gatti. 2002. "Decentralization and corruption: Evidence across countries,” Journal of Public Economics 83(3): 325-345.

Gehlbach, Scott, Konstantin Sonin, and Ekaterina Zhuravskaya. 2007. "Businessman candidates,” Available at SSRN: http://ssrn.com/abstract=917778 .

Grossman, Sanford and Oliver Hart. 1980. "Disclosure laws and takeover bids,” Journal of Finance 35(2): 323-334.

Hirshleifer, Jack. 1980. "Privacy: its origin, function, and future," The Journal of Legal Studies 9(4), 649-664.

Johnson, Joel and Jessica Wallack, 2006. "Electoral systems and the personal vote: Update of database from 'Particularism Around the World," San Diego: University of California.

Kaufmann, Daniel, Kraay, Aart, and Mastruzzi, Massimo. 2008. "Governance matters VII: Aggregate and individual governance indicators, 1996-2007,” World Bank Policy Research Working Paper No. 4654.

La Porta, Rafael, Florencio Lopez-de-Silanes, Andrei Shleifer, and Robert W. Vishny. 1999. "The quality of government," Journal of Law, Economics, and Organization 15(1): 222-79.

La Porta, Rafael, Florencio Lopez-de-Silanes, Cristian Pop-Eleches, and Andrei Shleifer. 2004. “Judicial checks and balances,” Journal of Political Economy 112(2): 445-70.

La Porta, Rafael, Florencio Lopez-de-Silanes, and Andrei Shleifer. 2006. "What works in securities laws?” Journal of Finance 61(1): 1-32.

La Porta, Rafael, Florencio Lopez-de-Silanes, and Andrei Shleifer. 2008. “The Economic 
Consequences of Legal Origins,” Journal of Economic Literature 46(2): 285-332.

McMillan, John and Pablo Zoido. 2004. "How to subvert democracy: Montesinos in Peru,” Journal of Economic Perspectives 18(4): 69-92.

Olken, Benjamin, 2007. "Monitoring corruption: Evidence from a field experiment in Indonesia,” Journal of Political Economy 115(2): 200-249.

Persson, Torsten and Guido Tabellini. 2003. The Economic Effects of Constitutions. Cambridge and London: MIT Press.

Polity IV Project. 2005. Polity IV Project: Political Regime Characteristics and Transitions. College Park: University of Maryland. Available online at http://www.bsos.umd.edu/cidcm/inscr/polity/index.htm

Posner, Richard. 1981. "The economics of privacy,” American Economic Review Papers and Proceedings 71(2): 405-409.

Przeworski, Adam, Michael Alvarez, Jose Cheibub, and Fernando Limongi. 2000. Democracy and development: political institutions and well-being in the world, 19501990. Cambridge: Cambridge University Press.

Reinikka, Ritva and Jakob Svensson. 2004. "The Power of Information: Evidence from a Newspaper Campaign to Reduce Capture,” World Bank Policy Research Working Paper No. 3239.

Schedler, Andreas, Larry Diamond, and Marc Plattner. 1999. The Self-Restraining State. Boulder, CO: Lynne Rienner Publishers, Inc.

Schneider, Frank. 2007. "Politicians, transparency, and corruption," Mimeo, Harvard University.

Stigler, George. 1980. "An introduction to privacy in economics and politics," The Journal of Legal Studies 9(4): 623-644.

Svensson, Jakob. 2005. "Eight questions about corruption," Journal of Economic Perspectives 19: 19-42.

Teorell, Jan, Sören Holmberg, and Bo Rothstein. 2008. The Quality of Government Dataset, version 7 Jan08. Göteborg University: The Quality of Government Institute, http://www.qog.pol.gu.se

Treisman, Daniel. 2000. "The causes of corruption: A cross-national study," Journal of Public Economics 76(3): 399-457. 
Treisman, Daniel. 2007. "What have we learnt about the causes of corruption from ten years of cross-national empirical research?” Mimeograph, University of California, Los Angeles.

United Nations Statistical Database (http://unstats.un.org)

World Development Indicators at http://devdata.worldbank.org/dataonline/. 
Table 1: Sample distribution

\begin{tabular}{|c|c|c|}
\hline & $\begin{array}{l}\text { Number of } \\
\text { countries }\end{array}$ & Country names \\
\hline Initial sample & 175 & \\
\hline Disclosures required by law & 109 & \\
\hline $\begin{array}{l}\text { Available to congress only } \\
\text { Publicly available by law }\end{array}$ & $\begin{array}{l}46 \\
63 \\
46\end{array}$ & \\
\hline $\begin{array}{l}\text { All publicly available directly w/o conditions } \\
\text { Only some disclosures publicly available } \\
\text { Available only through press } \\
\text { Available to public under conditions }\end{array}$ & $\begin{array}{l}6 \\
3 \\
9\end{array}$ & $\begin{array}{l}\text { Belgium,Colombia,Hungary,Italy,South Korea,Spain. } \\
\text { Armenia, Greece, Russia. } \\
\text { Bahamas,Belize,Canada,Cape Verde,Kazakhstan, } \\
\text { Mexico,Montenegro,Nicaragua,Spain. }\end{array}$ \\
\hline $\begin{array}{l}\text { Could obtain filled-out forms } \\
\text { Failed to obtain filled-out forms }\end{array}$ & & $\begin{array}{l}\text { Includes Bahrain (not publicly available by law). } \\
\text { Algeria,Angola,Bahamas,Belize,Cape Verde, Kazakhstan, } \\
\text { Mexico, Namibia,Nicaragua,Peru,Russia,Sri Lanka,Uganda. }\end{array}$ \\
\hline $\begin{array}{l}\text { Disclosures not required but exist in practice } \\
\text { Available to congress only } \\
\text { Publicly available in practice }\end{array}$ & & $\begin{array}{l}\text { Denmark,Finland,Norway,Singapore,Zambia. } \\
\text { Singapore. } \\
\text { Denmark,Finland,Norway,Zambia. }\end{array}$ \\
\hline Total publicly available in practice & 55 & \\
\hline
\end{tabular}


Table 2

Description of the variables

This table describes the variables collected for the 175 countries in our study. Unless otherwise noted, the sources of the variables are the laws, regulations and blank disclosure forms for each country.

1)Disclosure requirements and public availability of disclosures

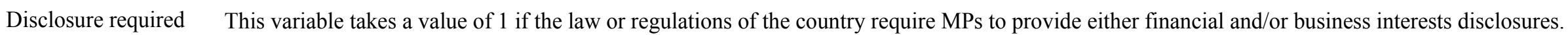
The variable takes a value of zero otherwise.

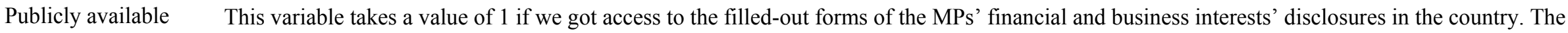
variable also equals 1 if the country has voluntary disclosures available to the public and we could access the filled-out forms of the MPs. The variable takes a value of 0.5 if the country has two different standards for public availability of disclosures for the financial and the business interest forms, and only one of them was available (Belgium, Colombia, Hungary, Italy, and Spain). The variable takes a value of zero if we failed to get access to the filled-out forms of the MPs or if the country has no public disclosure required from MPs.

Values available to congress

Sources available to congress

\section{2) Measures of disclosure based on blank disclosure forms}

The index of values available to congress measures the ratio of all value items contained in the country's blank disclosure form available to congress over all value items potentially disclosed in the artificial "universal" form. It measures how many "conceivable" disclosures of value items are required to be disclosed to congress (or to an alternative government agency) by the MP. To construct the measures of the content of disclosures, we use the blank disclosure forms collected from the 106 countries with available blank forms. We begin by constructing an artificial "universal disclosure form," which incorporates all the information that any country requires its MPs to disclose. We then compare each country's blank disclosure form to the universal form. For each item, we assign a score of 1 when the item is included in the country's blank form requesting to provide disaggregated values (i.e., the value of each property, of each wage, etc...). We assign a score of 0.5 for each item included in the country's blank form requesting to provide only an aggregate value (i.e., the total value of all properties owned, total value of wages, etc...). We assign a score of 0 when the country's blank form does not include the specific item. When the country imposes a binding restriction (i.e., which cannot be overturned) on a given item (i.e., the business activities of the MPs, their abilities to receive gifts, or to own stocks) we code the restriction as the highest possible disclosure standard. The scores of each item of disclosure in a particular area are then averaged to create an equally-weighted score of values for each area of disclosure. Finally, the overall values score of the blank form is calculated as the equally-weighted average across all six categories with potential disclosure of value items (i.e., assets, liabilities, income, expenditure, gifts, and travel).

The index of sources available to congress measures the ratio of all source items contained in the country's blank disclosure form available to congress over all source items potentially disclosed in the artificial "universal" form (see above). We compare each country's blank disclosure form to the universal form. For each item, we assign a score of 1 when the country's blank form requests the information needed to identify the source (i.e., the precise location of assets, the identity of creditors, the source of income, gifts and travel, and the identity of parties with whom they work, they have relationships or associations, or with whom they have entered into post-tenure agreements). We assign a score of 0 when the country's blank form does not request the identification of the source of the specific item, or when the information requested is not sufficient to identify the item's source. When the country imposes a binding restriction (i.e., which cannot be overturned) on a given item (i.e., the business activities of the MPs, their abilities to receive gifts, or to own stocks) we code the restriction as the highest possible disclosure standard. The scores of each item of disclosure in a particular area are then averaged to create an equally-weighted score of sources for each area of disclosure. Finally, the overall sources score of the blank form is calculated as the equally-weighted average across all six categories with potential disclosure of source items (i.e., assets, liabilities, income, conflicts of interest, gifts, and travel). 
Values publicly available

Sources publicly available
The index of values publicly available measures the ratio of all value items contained in the country's disclosure form available to the public over all value items potentially disclosed in the artificial "universal" form. It measures how many "conceivable" disclosures of value items are publicly available in practice. This index is constructed following the same methodology described above for the score of "values available to congress," but only takes into account completed disclosures we were able to obtain.

The index of sources publicly available measures the ratio of all source items contained in the country's disclosure form available to the public over all source items potentially disclosed in the artificial "universal" form. It measures how many "conceivable" disclosures of source items are publicly available in practice. This index is constructed following the same methodology described above for the score of "sources available to congress," but it only takes account of completed disclosures we were able to obtain.

\section{3) Enforcement indices}

Registrar strength

The index is the weighted average of three separate variables: (1) Registrar unit is independent from parliament. This variable takes a value of 1 if there is a registrar where the MPs turn in their forms and this unit is independent from parliament, and zero otherwise. (2) Registrar unit publishes compliance data by law. This variable takes a value of 1 if the law specifically requires that the registrar unit publishes compliance data by MPs, or if the law provides that disclosures are publicly available, and zero otherwise. (3) Penalties for MPs' failure to comply. This variable takes a value of 1 if the law establishes penalties for those MPs who do not submit their disclosures, or for any breach of the law that requires submission of the disclosures, and zero otherwise.

Checking unit strength

The index is the weighted average of three separate variables: (1) Agency/Body that routinely checks the disclosures is independent from parliament. This variable takes a value of 1 if there is an agency/body mandated by the law that is in charge of routinely checking the content of the disclosure forms and if this unit is independent from parliament. The variable takes a value of zero otherwise. (2) Data integrity unit publishes compliance data by law. This variable takes a value of 1 if the law specifically requires that the data integrity unit publishes the results of checking the content of the disclosure forms by MPs, and zero otherwise. (3) Penalties for submitting false information. This variable takes a value of 1 if the law specifically establishes penalties for those MPs who provide false information in the disclosures. The variable takes a value of zero if there are general penalties for a breach of the law, but not specific penalties for providing false information, or if there are no penalties established at all.

\section{4) Corruption measures}

ICRG corruption index (2003-2007)

Kaufmann corruption index (2003-2005)

\section{Transparency}

International corruption index (2003-2007)
The average of the index of corruption from the International Country Risk Guide between 2003 and 2007. The scale of the index is from 0 to 6 , where higher numbers mean lower corruption. Source: International Country Risk Guide, Political Risk Services. www.prsgroup.com.

The average score of the Kaufmann corruption index between 2003 and 2005 . The range of the score is from -2.5 to +2.5 , with a higher score indicating better governance. Source: Kaufmann et al (2008).

The average score of the Transparency International index of corruption perception between 2003 and 2007 . The index provides a measure of the extent to which corruption is perceived to exist in the public and political sectors. The index focuses on corruption in the public sector and defines corruption as the abuse of public office for private gain. It is based on assessments by experts and opinion surveys. The index ranges between 0 (highly corrupt) and 10 (highly clean). Source: www.transparency.org. 
Heritage Foundation corruption index (2003-2007)

GCR corruption index (2003-2007)

Firms that pay bribes (\%) The average score of the Heritage Foundation index of corruption between 2003 and 2007 . The index is based on quantitative data that assess the
perception of corruption in the business environment, including levels of governmental, legal, judicial and administrative corruption. The index is based on the index of Transparency International but supplemented with quantitative information from other sources. The scale of the index is from 0 to 100, where higher numbers mean less corruption. Source: www.heritage.org.

The average score of the Global Competitiveness Report index of corruption between 2003 and 2007. The index is based on survey measures that include questions about the business costs of corruption. The scale of the index is from 0 to 7 , where higher numbers mean less corruption. Source: International Country Risk Guide, Political Risk Services. www.prsgroup.com.

\section{Log GNI per capita} 2006

\section{Protestant} population

French civil law, German civil law and Scandinavian law dummies Democracy (19752006)

Proportional representation (1975-2006)

Party versus candidate specific voting

Government ownership of the press $(\%)$

\section{Logarithmic of per capita Gross National Income Atlas Method (in US dollars) in 2006. Source: World Development Indicators at} http://devdata.worldbank.org/dataonline/.

The percentage of protestant population in the country in 1980. Source: La Porta et al (1999).

Identifies the legal origin of the company law or commercial law of each country. Each dummy variable is equal to 1 if the origin of the company law or commercial law of the country is French, German or Scandinavian, respectively, and zero otherwise. The omitted legal origin is English Common law. Source: La Porta et al (2008).

Average democracy score from Polity IV for the years between 1975 and 2006. It is a measure of the degree of democracy in a given country based on: (1) the competitiveness of political participation; (2) the openness and competitiveness of executive recruitment; and (3) the constraints on the chief executive. The democracy indicator is an additive eleven-point scale ranging from 0 to 10 , where higher values equal a higher degree of institutionalized democracy. Source: Jaggers and Marshall (2000) and updates of the Polity IV Database.

Average of the proportional representation score for the years between 1975 and 2006 . The variable equals 3 if 100 percent of the seats are assigned via proportional rule, 2 if the majority of seats are assigned via proportional rule, 1 if a minority of seats is assigned proportionally, and zero if no seats are assigned through a proportional rule. Source: Beck et al (2001) and updates of World Bank Database of Political Institutions.

Party versus candidate specific voting score for the year 2005. The variable captures the distinction between casting votes either for parties or for individual candidates in the lower (or only) house. The variable takes a value of zero in countries where voters have only one vote for a party. It takes a value of 1 in countries where voters can vote for a party or a candidate, where voters have multiple votes for multiple candidates, or where votes for a party or candidate are observationally equivalent. Finally, it takes a value of 2 for countries where voters have one vote for an individual candidate. Source: Johnson \& Wallack (2006).

\footnotetext{
Market share of state-owned newspapers out of the aggregate market share of the five largest daily newspapers (by circulation). Source: Djankov et al
} (2003). 
Government ownership (\%)

Market share of state-owned television stations out of the aggregate market share of the five largest television stations (by viewership). Source:

Newspaper circulation

Judicial independence

Djankov et al (2003).

Logarithm of newspapers and periodicals circulation per thousand inhabitants in the year 2000 (or closest available). Source: United Nations Statistical Database (http://unstats.un.org).

The average of three variables: (1) Tenure of Supreme Court Judges; (2) Tenure of the Administrative Court Judges; and (3) Case Law. Source: La Porta et al (2004). 
Table 3: Disclosure and enforcement indices by income groups

\begin{tabular}{|c|c|c|c|c|c|c|c|c|}
\hline & \multicolumn{2}{|c|}{$\begin{array}{l}\text { Requirements and } \\
\text { public availabitily }\end{array}$} & \multicolumn{4}{|c|}{$\begin{array}{c}\text { Form content (based on universal form } \\
\text { concept) }\end{array}$} & \multicolumn{2}{|c|}{ Enforcement } \\
\hline & $\begin{array}{l}\text { Disclosure } \\
\text { required }\end{array}$ & $\begin{array}{l}\text { Publicly } \\
\text { available }\end{array}$ & $\begin{array}{c}\text { Values } \\
\text { available to } \\
\text { congress } \\
\end{array}$ & $\begin{array}{c}\text { Sources } \\
\text { available to } \\
\text { congress } \\
\end{array}$ & $\begin{array}{c}\text { Values } \\
\text { publicly } \\
\text { available } \\
\end{array}$ & $\begin{array}{l}\text { Sources } \\
\text { publicly } \\
\text { available }\end{array}$ & $\begin{array}{l}\text { Registrar } \\
\text { strength }\end{array}$ & $\begin{array}{c}\text { Checking } \\
\text { unit } \\
\text { strength } \\
\end{array}$ \\
\hline & \multicolumn{8}{|c|}{ Panel A: Means } \\
\hline Full sample (175) & 0.62 & 0.29 & 0.23 & 0.31 & 0.09 & 0.15 & 0.32 & 0.21 \\
\hline Countries with blank form (106) & 0.95 & 0.49 & 0.37 & 0.48 & 0.14 & 0.24 & 0.50 & 0.34 \\
\hline
\end{tabular}

Panel B: Means by income groups (and significance of t-tests of group vs. the rest)

\begin{tabular}{lll|llll|lll} 
High income (37) & $0.76^{\mathrm{c}}$ & $0.61^{\mathrm{a}}$ & 0.20 & $0.41^{\mathrm{a}}$ & 0.09 & $0.32^{\mathrm{a}}$ & 0.27 & 0.19 \\
Upper middle income (30) & $0.83^{\mathrm{a}}$ & $0.42^{\mathrm{b}}$ & $0.35^{\mathrm{a}}$ & $0.45^{\mathrm{a}}$ & $0.16^{\mathrm{a}}$ & $0.25^{\mathrm{b}}$ & $0.51^{\mathrm{a}}$ & $0.37^{\mathrm{a}}$ \\
Lower middle income (59) & $0.66^{\mathrm{a}}$ & 0.21 & $0.29^{\mathrm{c}}$ & 0.31 & 0.08 & $0.08^{\mathrm{a}}$ & 0.37 & 0.24 \\
Low income (49) & $0.35^{\mathrm{a}}$ & $0.08^{\mathrm{a}}$ & $0.11^{\mathrm{a}}$ & $0.12^{\mathrm{a}}$ & $0.04^{\mathrm{b}}$ & $0.03^{\mathrm{a}}$ & $0.18^{\mathrm{a}}$ & $0.10^{\mathrm{a}}$
\end{tabular}

\footnotetext{
Notes:

Number of countries in parentheses.

Significance levels: (a) if $\mathrm{p}<0.01$; (b) if $\mathrm{p}<0.05$; (c.) if $\mathrm{p}<0.10$.
} 
Table 4: Cross-sectional determinants of disclosure and enforcement

\begin{tabular}{|c|c|c|c|c|c|c|c|c|}
\hline \multirow[b]{2}{*}{ Dependent variable is: } & \multicolumn{2}{|c|}{$\begin{array}{l}\text { Requirements and } \\
\text { public availabitily }\end{array}$} & \multicolumn{4}{|c|}{$\begin{array}{c}\text { Form Content (based on universal form } \\
\text { concept) }\end{array}$} & \multicolumn{2}{|c|}{ Enforcement } \\
\hline & $\begin{array}{c}\text { Disclosure } \\
\text { required }\end{array}$ & $\begin{array}{l}\text { Publicly } \\
\text { available }\end{array}$ & $\begin{array}{c}\text { Values } \\
\text { available to } \\
\text { congress }\end{array}$ & $\begin{array}{c}\text { Sources } \\
\text { available to } \\
\text { congress } \\
\end{array}$ & $\begin{array}{c}\text { Values } \\
\text { publicly } \\
\text { available } \\
\end{array}$ & $\begin{array}{c}\text { Sources } \\
\text { publicly } \\
\text { available }\end{array}$ & $\begin{array}{l}\text { Registrar } \\
\text { strength }\end{array}$ & $\begin{array}{c}\text { Checking } \\
\text { unit } \\
\text { strength } \\
\end{array}$ \\
\hline & \multicolumn{8}{|c|}{ Panel A: Controlling for religion } \\
\hline Log GNI percapita 2006 & $\begin{array}{c}0.0211 \\
{[0.0279]}\end{array}$ & $\begin{array}{c}0.0843^{\mathrm{a}} \\
{[0.0236]}\end{array}$ & $\begin{array}{l}-0.0222^{c} \\
{[0.0121]}\end{array}$ & $\begin{array}{c}0.0118 \\
{[0.0143]}\end{array}$ & $\begin{array}{c}0.0075 \\
{[0.0080]}\end{array}$ & $\begin{array}{c}0.0462^{\mathrm{a}} \\
{[0.0116]}\end{array}$ & $\begin{array}{l}-0.0181 \\
{[0.0200]}\end{array}$ & $\begin{array}{l}-0.0124 \\
{[0.0154]}\end{array}$ \\
\hline Democracy (1975-2006) & $\begin{array}{c}0.0717^{\mathrm{a}} \\
{[0.0129]}\end{array}$ & $\begin{array}{c}0.0356^{\mathrm{a}} \\
{[0.0123]}\end{array}$ & $\begin{array}{c}0.0342^{\mathrm{a}} \\
{[0.0057]}\end{array}$ & $\begin{array}{c}0.0427^{\mathrm{a}} \\
{[0.0069]}\end{array}$ & $\begin{array}{c}0.0121^{\mathrm{a}} \\
{[0.0043]}\end{array}$ & $\begin{array}{l}0.0193^{\mathrm{a}} \\
{[0.0060]}\end{array}$ & $\begin{array}{c}0.0350^{\mathrm{a}} \\
{[0.0093]}\end{array}$ & $\begin{array}{c}0.0291^{\mathrm{a}} \\
{[0.0076]}\end{array}$ \\
\hline Protestant population & $\begin{array}{l}-0.0061^{\mathrm{a}} \\
{[0.0020]}\end{array}$ & $\begin{array}{c}0.0016 \\
{[0.0015]}\end{array}$ & $\begin{array}{l}-0.0025^{b} \\
{[0.0010]}\end{array}$ & $\begin{array}{l}-0.0025^{\mathrm{c}} \\
{[0.0015]}\end{array}$ & $\begin{array}{l}-0.0008 \\
{[0.0007]}\end{array}$ & $\begin{array}{c}0.0015^{\mathrm{C}} \\
{[0.0009]}\end{array}$ & $\begin{array}{l}-0.0030^{\mathrm{b}} \\
{[0.0012]}\end{array}$ & $\begin{array}{l}-0.0027^{\mathrm{a}} \\
{[0.0009]}\end{array}$ \\
\hline Constant & $\begin{array}{c}0.2282 \\
{[0.1894]}\end{array}$ & $\begin{array}{l}-0.5268^{\mathrm{a}} \\
{[0.1502]}\end{array}$ & $\begin{array}{c}0.2887^{\mathrm{a}} \\
{[0.0916]}\end{array}$ & $\begin{array}{c}0.0547 \\
{[0.1022]}\end{array}$ & $\begin{array}{l}-0.0115 \\
{[0.0571]}\end{array}$ & $\begin{array}{l}-0.3124^{\mathrm{a}} \\
{[0.0777]}\end{array}$ & $\begin{array}{c}0.3453^{\mathrm{c}} \\
{[0.1365]}\end{array}$ & $\begin{array}{c}0.2163^{\mathrm{b}} \\
{[0.1035]}\end{array}$ \\
\hline \multirow{2}{*}{ R-squared } & $\begin{array}{l}149 \\
0.31\end{array}$ & $\begin{array}{l}149 \\
0.31\end{array}$ & $\begin{array}{c}142 \\
0.16\end{array}$ & $\begin{array}{l}142 \\
0.29\end{array}$ & $\begin{array}{l}149 \\
0.08\end{array}$ & $\begin{array}{l}149 \\
0.32\end{array}$ & $\begin{array}{l}149 \\
0.10\end{array}$ & $\begin{array}{l}149 \\
0.12\end{array}$ \\
\hline & \multicolumn{8}{|c|}{ Panel B: Controlling for legal origins } \\
\hline Log GNI percapita 2006 & $\begin{array}{c}0.0384 \\
{[0.0280]}\end{array}$ & $\begin{array}{c}0.0542^{\mathrm{b}} \\
{[0.0219]}\end{array}$ & $\begin{array}{c}-0.0173 \\
{[0.0126]}\end{array}$ & $\begin{array}{c}0.0213 \\
{[0.0151]}\end{array}$ & $\begin{array}{l}-0.0026 \\
{[0.0075]}\end{array}$ & $\begin{array}{c}0.0352^{\mathrm{a}} \\
{[0.0124]}\end{array}$ & $\begin{array}{c}-0.0143 \\
{[0.0197]}\end{array}$ & $\begin{array}{c}-0.0044 \\
{[0.0149]}\end{array}$ \\
\hline Democracy (1975-2006) & $\begin{array}{c}0.0635^{\mathrm{a}} \\
{[0.0123]}\end{array}$ & $\begin{array}{c}0.0357^{\mathrm{a}} \\
{[0.0112]}\end{array}$ & $\begin{array}{c}0.0314^{\mathrm{a}} \\
{[0.0053]}\end{array}$ & $\begin{array}{c}0.0402^{\mathrm{a}} \\
{[0.0067]}\end{array}$ & $\begin{array}{c}0.0101^{\mathrm{a}} \\
{[0.0033]}\end{array}$ & $\begin{array}{c}0.0211^{\mathrm{a}} \\
{[0.0056]}\end{array}$ & $\begin{array}{c}0.0295^{\mathrm{a}} \\
{[0.0084]}\end{array}$ & $\begin{array}{c}0.0239^{a} \\
{[0.0070]}\end{array}$ \\
\hline French civil law dummy & $\begin{array}{c}0.0447 \\
{[0.0834]}\end{array}$ & $\begin{array}{l}-0.0047 \\
{[0.0733]}\end{array}$ & $\begin{array}{c}0.0034 \\
{[0.0479]}\end{array}$ & $\begin{array}{l}-0.0580 \\
{[0.0508]}\end{array}$ & $\begin{array}{c}0.0136 \\
{[0.0278]}\end{array}$ & $\begin{array}{l}-0.0489 \\
{[0.0431]}\end{array}$ & $\begin{array}{c}0.0416 \\
{[0.0607]}\end{array}$ & $\begin{array}{c}0.0510 \\
{[0.0449]}\end{array}$ \\
\hline German civil law dummy & $\begin{array}{c}0.1289 \\
{[0.0870]}\end{array}$ & $\begin{array}{l}0.4440^{\mathrm{a}} \\
{[0.1062]}\end{array}$ & $\begin{array}{c}0.0596 \\
{[0.0676]}\end{array}$ & $\begin{array}{c}0.0019 \\
{[0.0713]}\end{array}$ & $\begin{array}{c}0.2206^{\mathrm{a}} \\
{[0.0590]}\end{array}$ & $\begin{array}{c}0.1368^{\mathrm{C}} \\
{[0.0808]}\end{array}$ & $\begin{array}{c}0.1692^{\mathrm{C}} \\
{[0.0976]}\end{array}$ & $\begin{array}{c}0.0774 \\
{[0.0698]}\end{array}$ \\
\hline Scandinavian law dummy & $\begin{array}{l}-0.8317^{\mathrm{a}} \\
{[0.2358]}\end{array}$ & $\begin{array}{c}0.3822^{\mathrm{a}} \\
{[0.0914]}\end{array}$ & $\begin{array}{l}-0.3401^{\mathrm{a}} \\
{[0.0627]}\end{array}$ & $\begin{array}{l}-0.5641^{\mathrm{a}} \\
{[0.0913]}\end{array}$ & $\begin{array}{l}-0.0067 \\
{[0.0658]}\end{array}$ & $\begin{array}{c}0.0901 \\
{[0.0942]}\end{array}$ & $\begin{array}{l}-0.3208^{\mathrm{a}} \\
{[0.1011]}\end{array}$ & $\begin{array}{l}-0.2988^{\mathrm{a}} \\
{[0.0546]}\end{array}$ \\
\hline Constant & $\begin{array}{c}0.0313 \\
{[0.1967]}\end{array}$ & $\begin{array}{l}-0.3251^{\mathrm{b}} \\
{[0.1452]}\end{array}$ & $\begin{array}{c}0.2322^{\mathrm{b}} \\
{[0.1034]}\end{array}$ & $\begin{array}{c}0.0110 \\
{[0.1148]}\end{array}$ & $\begin{array}{c}0.0345 \\
{[0.0610]}\end{array}$ & $\begin{array}{l}-0.2023^{\mathrm{b}} \\
{[0.0841]}\end{array}$ & $\begin{array}{c}0.2637^{\mathrm{C}} \\
{[0.1519]}\end{array}$ & $\begin{array}{c}0.1074 \\
{[0.1088]}\end{array}$ \\
\hline Observations & 153 & 153 & 146 & 146 & 153 & 153 & 153 & 153 \\
\hline R-squared & 0.34 & 0.41 & 0.19 & 0.37 & 0.23 & 0.36 & 0.12 & 0.12 \\
\hline $\begin{array}{l}\text { Robust standard errors in br } \\
\text { Significance levels: (a) if } \mathrm{p}\end{array}$ & ; (b) if $\mathrm{p}$ & ; (c.) if $\mathrm{p}$ & & & & & & \\
\hline
\end{tabular}


Table 5: Determinants of the wedge between disclosures to public and to congress

Dependent variable is: Public availability Values disclosure Sources disclousure wedge wedge wedge

Panel A: Controlling for religion

$\begin{array}{lccc}\text { Log GNI percapita 2006 } & 0.1314^{\mathrm{a}} & 0.0750^{\mathrm{a}} & 0.0742^{\mathrm{a}} \\ & {[0.0481]} & {[0.0211]} & {[0.0237]} \\ \text { Democracy (1975-2006) } & -0.0101 & -0.0128 & -0.0080 \\ & {[0.0206]} & {[0.0086]} & {[0.0100]} \\ \text { Protestant population } & 0.0087^{\mathrm{a}} & 0.0010 & 0.0039^{\mathrm{b}} \\ & {[0.0027]} & {[0.0014]} & {[0.0018]} \\ \text { Constant } & -1.6168^{\mathrm{a}} & -0.7918^{\mathrm{a}} & -0.8621^{\mathrm{a}} \\ & {[0.3528]} & {[0.1638]} & {[0.1775]} \\ \text { Observations } & 94 & 94 & 94 \\ \text { R-squared } & 0.28 & 0.15 & 0.24 \\ & & & \end{array}$

Panel B: Controlling for legal origins

Log GNI percapita 2006

$0.0827^{\circ}$

$0.0551^{\mathrm{a}}$

$0.0509^{\mathrm{b}}$

[0.0439]

Democracy (1975-2006)

0.0031

[0.0197]

[0.0184]

French civil law dummy

$-0.1367$

$-0.0111$

[0.1277]

German civil law dummy

$0.3005^{\mathrm{b}}$

0.0031

[0.0218]

Scandinavian law dummy

[0.1237]

$1.0084^{\mathrm{a}}$

[0.2487]

Constant

$-1.1836^{\mathrm{a}}$

Observations

[0.3597]

R-squared

96

0.35

0.0031

[0.0698]

$0.1786^{\mathrm{a}}$

[0.0673]

$0.2581^{\mathrm{a}}$

[0.0973]

$-0.6616^{\mathrm{a}}$

[0.1717]

96

$-0.0022$

[0.0092]

$-0.0181$

[0.0736]

$0.1399^{\mathrm{c}}$

[0.0804]

$0.5554^{\mathrm{a}}$

$[0.1436]$

$-0.6816^{\mathrm{a}}$

[0.1820]

0.23

96

Robust standard errors in brackets

Significance levels: (a) if $\mathrm{p}<0.01$; (b) if $\mathrm{p}<0.05$; (c.) if $\mathrm{p}<0.10$. 
Table 6: Disclosure and perceived corruption.

\begin{tabular}{|c|c|c|c|c|c|c|c|c|}
\hline \multicolumn{9}{|c|}{ Dependent variable in all regressions: ICRG corruption index (2003-2007) } \\
\hline \multicolumn{2}{|l|}{ Additional control variable is: } & $\begin{array}{c}\text { Democracy } \\
(1975-2006)\end{array}$ & $\begin{array}{l}\text { Proportional } \\
\text { representation } \\
(1975-2006)\end{array}$ & $\begin{array}{c}\text { Party vs } \\
\text { candidate- } \\
\text { specific voting }\end{array}$ & $\begin{array}{c}\text { Government } \\
\text { owned press } \\
(\%)\end{array}$ & $\begin{array}{c}\text { Government } \\
\text { owned TV } \\
(\%)\end{array}$ & $\begin{array}{l}\text { Newspaper } \\
\text { circulation }\end{array}$ & $\begin{array}{c}\text { Judicial } \\
\text { independence }\end{array}$ \\
\hline \multicolumn{9}{|c|}{ Panel A: No disclosure variables } \\
\hline \multirow[t]{2}{*}{ Additional control variable } & & $0.1780^{\mathrm{a}}$ & $0.5957^{\mathrm{a}}$ & $0.3615^{\mathrm{b}}$ & $-1.4662^{\mathrm{a}}$ & $-0.7438^{\mathrm{b}}$ & $0.5068^{\mathrm{a}}$ & $1.2599^{\mathrm{a}}$ \\
\hline & & {$[0.0245]$} & {$[0.209]$} & {$[0.172]$} & {$[0.226]$} & {$[0.314]$} & {$[0.0756]$} & {$[0.375]$} \\
\hline \multirow[t]{2}{*}{ Constant } & & $1.6175^{\mathrm{a}}$ & $2.2052^{\mathrm{a}}$ & $2.4296^{\mathrm{a}}$ & $3.0504^{\mathrm{a}}$ & $3.1357^{\mathrm{a}}$ & $0.7706^{\mathrm{b}}$ & $1.9239^{\mathrm{a}}$ \\
\hline & & {$[0.0994]$} & {$[0.154]$} & {$[0.167]$} & {$[0.155]$} & {$[0.240]$} & {$[0.307]$} & {$[0.226]$} \\
\hline \multicolumn{2}{|l|}{ Observations } & 137 & 126 & 104 & 89 & 89 & 78 & 68 \\
\hline \multicolumn{2}{|l|}{ R-squared } & 0.34 & 0.06 & 0.02 & 0.22 & 0.04 & 0.41 & 0.09 \\
\hline \multicolumn{9}{|c|}{ Panel B: Controlling for income per capita and disclosure requirement } \\
\hline \multirow[t]{2}{*}{ Additional control variable } & & $0.1115^{\mathrm{a}}$ & 0.1308 & 0.04554 & -0.2727 & -0.1293 & -0.0199 & $0.8536^{\mathrm{a}}$ \\
\hline & & {$[0.0281]$} & {$[0.177]$} & {$[0.143]$} & {$[0.256]$} & {$[0.292]$} & {$[0.0967]$} & {$[0.299]$} \\
\hline \multirow[t]{2}{*}{ Log GNI per capita 2006} & $0.4659^{\mathrm{a}}$ & $0.3429^{\mathrm{a}}$ & $0.5202^{\mathrm{a}}$ & $0.5604^{\mathrm{a}}$ & $0.5419^{\mathrm{a}}$ & $0.5682^{\mathrm{a}}$ & $0.6426^{\mathrm{a}}$ & $0.5706^{\mathrm{a}}$ \\
\hline & {$[0.0594]$} & {$[0.0594]$} & {$[0.0635]$} & {$[0.0682]$} & {$[0.0678]$} & {$[0.0643]$} & {$[0.104]$} & {$[0.0623]$} \\
\hline \multirow[t]{2}{*}{ Disclosure required } & -0.1963 & $-0.5368^{\mathrm{a}}$ & $-0.4913^{\mathrm{b}}$ & $-0.4427^{\mathrm{c}}$ & $-0.4630^{\mathrm{c}}$ & $-0.4546^{\mathrm{c}}$ & $-0.4515^{\mathrm{c}}$ & -0.2371 \\
\hline & {$[0.186]$} & {$[0.178]$} & {$[0.200]$} & {$[0.234]$} & {$[0.249]$} & {$[0.262]$} & {$[0.245]$} & {$[0.256]$} \\
\hline \multirow[t]{2}{*}{ Constant } & $-1.1753^{\mathrm{a}}$ & -0.4752 & $-1.4405^{\mathrm{a}}$ & $-1.7168^{a}$ & $-1.5051^{\mathrm{b}}$ & $-1.7218^{\mathrm{a}}$ & $-2.3168^{a}$ & $-2.5299^{\mathrm{a}}$ \\
\hline & {$[0.418]$} & {$[0.415]$} & {$[0.432]$} & {$[0.493]$} & {$[0.597]$} & {$[0.620]$} & {$[0.625]$} & {$[0.532]$} \\
\hline Observations & 132 & 128 & 121 & 99 & 86 & 86 & 76 & 66 \\
\hline \multirow{2}{*}{ R-squared } & 0.45 & 0.51 & 0.51 & 0.55 & 0.57 & 0.56 & 0.60 & 0.63 \\
\hline & \multicolumn{7}{|c|}{ Panel C: Controlling for income per capita and publicly available disclosures } & \\
\hline \multirow[t]{2}{*}{ Additional control variable } & & $0.0634^{\mathrm{b}}$ & 0.00083 & 0.1002 & 0.04948 & 0.1687 & -0.0628 & $0.5286^{\mathrm{c}}$ \\
\hline & & {$[0.0266]$} & {$[0.174]$} & {$[0.134]$} & {$[0.265]$} & {$[0.254]$} & {$[0.0910]$} & {$[0.286]$} \\
\hline \multirow[t]{2}{*}{ Log GNI per capita 2006} & $0.3815^{\mathrm{a}}$ & $0.3091^{\mathrm{a}}$ & $0.4272^{\mathrm{a}}$ & $0.4858^{\mathrm{a}}$ & $0.4856^{\mathrm{a}}$ & $0.4883^{\mathrm{a}}$ & $0.5855^{\mathrm{a}}$ & $0.4617^{\mathrm{a}}$ \\
\hline & {$[0.0523]$} & {$[0.0607]$} & {$[0.0596]$} & {$[0.0653]$} & {$[0.0726]$} & {$[0.0664]$} & {$[0.101]$} & {$[0.0720]$} \\
\hline \multirow[t]{2}{*}{ Publicly available } & $0.4893^{\mathrm{a}}$ & $0.3615^{\mathrm{b}}$ & $0.3540^{\mathrm{b}}$ & $0.2976^{\mathrm{c}}$ & $0.4316^{\mathrm{b}}$ & $0.4365^{\mathrm{b}}$ & $0.4511^{\mathrm{b}}$ & $0.6732^{\mathrm{b}}$ \\
\hline & {$[0.172]$} & {$[0.181]$} & {$[0.176]$} & {$[0.179]$} & {$[0.206]$} & {$[0.200]$} & {$[0.214]$} & {$[0.272]$} \\
\hline \multirow[t]{2}{*}{ Constant } & $-0.7893^{\mathrm{c}}$ & -0.4636 & $-1.0898^{\mathrm{b}}$ & $-1.6110^{\mathrm{a}}$ & $-1.6508^{b}$ & $-1.7679^{\mathrm{a}}$ & $-2.2114^{\mathrm{a}}$ & $-1.8061^{\mathrm{a}}$ \\
\hline & {$[0.412]$} & {$[0.438]$} & {$[0.438]$} & {$[0.516]$} & {$[0.637]$} & {$[0.601]$} & {$[0.627]$} & {$[0.608]$} \\
\hline Observations & 132 & 128 & 121 & 99 & 86 & 86 & 76 & 66 \\
\hline R-squared & 0.48 & 0.49 & 0.49 & 0.54 & 0.56 & 0.57 & 0.60 & 0.66 \\
\hline $\begin{array}{l}\text { Robust standard errors in brackets } \\
\text { Significance levels: (a) if } p<0.01 \text {; (b }\end{array}$ & $\mathrm{p}<0.05$ & if $\mathrm{p}<0.10$ & & & & & & \\
\hline
\end{tabular}


Table 7: Disclosure and perceived corruption; values and sources.

\begin{tabular}{|c|c|c|c|c|c|c|c|c|}
\hline \multicolumn{9}{|c|}{ Dependent variable in all regressions is: ICRG corruption index (2003-2007) } \\
\hline Additional control variable is: & & $\begin{array}{c}\text { Democracy } \\
(1975-2006)\end{array}$ & $\begin{array}{l}\text { Proportional } \\
\text { representation } \\
(1975-2006)\end{array}$ & $\begin{array}{c}\text { Party vs } \\
\text { candidate- } \\
\text { specific voting }\end{array}$ & $\begin{array}{c}\text { Government } \\
\text { owned press } \\
(\%)\end{array}$ & $\begin{array}{c}\text { Government } \\
\text { owned TV } \\
(\%)\end{array}$ & $\begin{array}{l}\text { Newspaper } \\
\text { circulation }\end{array}$ & $\begin{array}{c}\text { Judicial } \\
\text { independence }\end{array}$ \\
\hline \multicolumn{9}{|c|}{ Panel A: Controlling for income per capita and values publicly available } \\
\hline Additional control variable & & $\begin{array}{c}0.0804^{\mathrm{a}} \\
{[0.0270]}\end{array}$ & $\begin{array}{c}0.0513 \\
{[0.1771]}\end{array}$ & $\begin{array}{c}0.0913 \\
{[0.1386]}\end{array}$ & $\begin{array}{c}-0.1352 \\
{[0.2775]}\end{array}$ & $\begin{array}{c}0.1040 \\
{[0.2720]}\end{array}$ & $\begin{array}{c}-0.0543 \\
{[0.0894]}\end{array}$ & $\begin{array}{c}0.8143^{\mathrm{a}} \\
{[0.2994]}\end{array}$ \\
\hline Log GNI per capita 2006 & $\begin{array}{c}0.4482^{\mathrm{a}} \\
{[0.0535]}\end{array}$ & $\begin{array}{c}0.3416^{\mathrm{a}} \\
{[0.0605]}\end{array}$ & $\begin{array}{c}0.4801^{\mathrm{a}} \\
{[0.0593]}\end{array}$ & $\begin{array}{c}0.5364^{\mathrm{a}} \\
{[0.0645]}\end{array}$ & $\begin{array}{c}0.5303^{\mathrm{a}} \\
{[0.0709]}\end{array}$ & $\begin{array}{c}0.5514^{\mathrm{a}} \\
{[0.0656]}\end{array}$ & $\begin{array}{c}0.6466^{\mathrm{a}} \\
{[0.1010]}\end{array}$ & $\begin{array}{c}0.5528^{\mathrm{a}} \\
{[0.0634]}\end{array}$ \\
\hline Values publicly available & $\begin{array}{c}0.0399 \\
{[0.4017]}\end{array}$ & $\begin{array}{c}-0.1915 \\
{[0.4160]}\end{array}$ & $\begin{array}{c}-0.1753 \\
{[0.4173]}\end{array}$ & $\begin{array}{c}-0.3150 \\
{[0.4321]}\end{array}$ & $\begin{array}{c}-0.0946 \\
{[0.5285]}\end{array}$ & $\begin{array}{c}0.0073 \\
{[0.4976]}\end{array}$ & $\begin{array}{c}-0.0124 \\
{[0.4915]}\end{array}$ & $\begin{array}{c}0.2223 \\
{[0.6952]}\end{array}$ \\
\hline Constant & $\begin{array}{l}-1.1675^{\mathrm{a}} \\
{[0.4218]}\end{array}$ & $\begin{array}{c}-0.6644 \\
{[0.4396]}\end{array}$ & $\begin{array}{l}-1.4005^{\mathrm{a}} \\
{[0.4410]}\end{array}$ & $\begin{array}{l}-1.8612^{\mathrm{a}} \\
{[0.5149]}\end{array}$ & $\begin{array}{l}-1.7782^{\mathrm{a}} \\
{[0.6235]}\end{array}$ & $\begin{array}{l}-2.0661^{\mathrm{a}} \\
{[0.6048]}\end{array}$ & $\begin{array}{l}-2.5537^{\mathrm{a}} \\
{[0.6356]}\end{array}$ & $\begin{array}{l}-2.5376^{\mathrm{a}} \\
{[0.5552]}\end{array}$ \\
\hline Observations & 132 & 128 & 121 & 99 & 86 & 86 & 76 & 66 \\
\hline R-squared & 0.44 & 0.48 & 0.48 & 0.53 & 0.54 & 0.54 & 0.57 & 0.63 \\
\hline
\end{tabular}

Panel B: Controlling for income per capita and sources publicly available

\begin{tabular}{|c|c|c|c|c|c|c|c|c|}
\hline Additional control variable & & $\begin{array}{c}0.0582^{\mathrm{b}} \\
{[0.0261]}\end{array}$ & $\begin{array}{c}0.0252 \\
{[0.1663]}\end{array}$ & $\begin{array}{c}0.1065 \\
{[0.1316]}\end{array}$ & $\begin{array}{c}0.0529 \\
{[0.2508]}\end{array}$ & $\begin{array}{c}0.2513 \\
{[0.2434]}\end{array}$ & $\begin{array}{c}-0.0404 \\
{[0.0868]}\end{array}$ & $\begin{array}{c}0.4806^{\mathrm{c}} \\
{[0.2842]}\end{array}$ \\
\hline \multirow[t]{2}{*}{ Log GNI per capita 2006} & $0.3698^{\mathrm{a}}$ & $0.3021^{\mathrm{a}}$ & $0.4096^{\mathrm{a}}$ & $0.4749^{\mathrm{a}}$ & $0.4634^{\mathrm{a}}$ & $0.4666^{\mathrm{a}}$ & $0.5709^{\mathrm{a}}$ & $0.4467^{\mathrm{a}}$ \\
\hline & {$[0.0554]$} & {$[0.0615]$} & {$[0.0635]$} & {$[0.0692]$} & {$[0.0762]$} & {$[0.0699]$} & {$[0.1033]$} & {$[0.0746]$} \\
\hline \multirow[t]{2}{*}{ Sources publicly available } & $1.0121^{\mathrm{a}}$ & $0.8079^{\mathrm{b}}$ & $0.8049^{\mathrm{b}}$ & $0.6183^{\mathrm{c}}$ & $0.9515^{\mathrm{a}}$ & $1.0010^{\mathrm{a}}$ & $0.7193^{\mathrm{b}}$ & $1.2660^{\mathrm{a}}$ \\
\hline & {$[0.3112]$} & {$[0.3278]$} & {$[0.3209]$} & {$[0.3192]$} & {$[0.3477]$} & {$[0.3444]$} & {$[0.3430]$} & {$[0.4168]$} \\
\hline \multirow[t]{2}{*}{ Constant } & -0.6995 & -0.3976 & $-0.9794^{\mathrm{b}}$ & $-1.5321^{\mathrm{a}}$ & $-1.4936^{\mathrm{b}}$ & $-1.6741^{\mathrm{a}}$ & $-2.1437^{\mathrm{a}}$ & $-1.6400^{\mathrm{b}}$ \\
\hline & {$[0.4293]$} & {$[0.4466]$} & {$[0.4614]$} & {$[0.5398]$} & {$[0.6444]$} & {$[0.6145]$} & {$[0.6454]$} & {$[0.6365]$} \\
\hline Observations & 132 & 128 & 121 & 99 & 86 & 86 & 76 & 66 \\
\hline R-squared & 0.49 & 0.50 & 0.50 & 0.55 & 0.58 & 0.59 & 0.60 & 0.67 \\
\hline
\end{tabular}

Robust standard errors in brackets

Significance levels: (a) if $\mathrm{p}<0.01$; (b) if $\mathrm{p}<0.05$; (c.) if $\mathrm{p}<0.10$. 
Table 8: Perceived corruption and publicly available disclosures: the role of democracy.

\begin{tabular}{|c|c|c|c|c|c|c|c|c|}
\hline \multicolumn{9}{|c|}{ Dependent variable in all regressions is: ICRG corruption index (2003-2007) } \\
\hline \multicolumn{2}{|l|}{$\begin{array}{r}\text { Additional control variable } \\
\text { is: }\end{array}$} & $\begin{array}{c}\text { Democracy } \\
(1975-2006)\end{array}$ & $\begin{array}{l}\text { Proportional } \\
\text { representation } \\
(1975-2006)\end{array}$ & $\begin{array}{c}\text { Party vs } \\
\text { candidate- } \\
\text { specific voting }\end{array}$ & $\begin{array}{c}\text { Government } \\
\text { owned press } \\
(\%)\end{array}$ & $\begin{array}{c}\text { Government } \\
\text { owned TV } \\
(\%)\end{array}$ & $\begin{array}{l}\text { Newspaper } \\
\text { circulation }\end{array}$ & $\begin{array}{c}\text { Judicial } \\
\text { independence }\end{array}$ \\
\hline \multicolumn{9}{|c|}{ Panel A: Above the mean democracy (1975-2006) score } \\
\hline \multirow[t]{2}{*}{ Additional control variable } & & 0.05348 & -0.00071 & 0.1266 & 0.9845 & 0.4210 & 0.1922 & $1.0431^{\mathrm{c}}$ \\
\hline & & {$[0.0559]$} & {$[0.215]$} & {$[0.150]$} & [1.507] & {$[0.455]$} & {$[0.172]$} & {$[0.532]$} \\
\hline \multirow[t]{2}{*}{ Log GNI percapita 2006} & $0.6938^{\mathrm{a}}$ & $0.6367^{\mathrm{a}}$ & $0.6935^{\mathrm{a}}$ & $0.6790^{\mathrm{a}}$ & $0.7789^{\mathrm{a}}$ & $0.7285^{\mathrm{a}}$ & $0.5845^{\mathrm{a}}$ & $0.6323^{\mathrm{a}}$ \\
\hline & {$[0.0701]$} & {$[0.0876]$} & {$[0.0714]$} & {$[0.0747]$} & {$[0.129]$} & {$[0.0954]$} & {$[0.149]$} & {$[0.124]$} \\
\hline \multirow[t]{2}{*}{ Publicly available } & $0.4877^{\mathrm{b}}$ & $0.5022^{b}$ & $0.4830^{\mathrm{b}}$ & $0.4170^{b}$ & $0.4362^{\mathrm{c}}$ & $0.4214^{\mathrm{c}}$ & $0.5545^{\mathrm{b}}$ & $0.6536^{\mathrm{b}}$ \\
\hline & {$[0.190]$} & {$[0.191]$} & {$[0.195]$} & {$[0.207]$} & {$[0.246]$} & {$[0.240]$} & {$[0.233]$} & {$[0.320]$} \\
\hline \multirow[t]{2}{*}{ Constant } & $-3.6106^{a}$ & $-3.5264^{\mathrm{a}}$ & $-3.6027^{\mathrm{a}}$ & $-3.5032^{\mathrm{a}}$ & $-4.3963^{a}$ & $-4.0660^{\mathrm{a}}$ & $-3.5099^{a}$ & $-3.8349^{a}$ \\
\hline & {$[0.628]$} & {$[0.625]$} & {$[0.641]$} & {$[0.662]$} & {$[1.235]$} & {$[0.852]$} & {$[0.791]$} & [1.248] \\
\hline Observations & 65 & 65 & 64 & 60 & 47 & 47 & 52 & 39 \\
\hline \multirow[t]{2}{*}{ R-squared } & 0.65 & 0.66 & 0.65 & 0.64 & 0.64 & 0.65 & 0.67 & 0.67 \\
\hline & \multicolumn{8}{|c|}{ Panel B: Below the mean democracy (1975-2006) score } \\
\hline \multirow[t]{2}{*}{ Additional control variable } & & 0.09033 & 0.1173 & 0.0504 & -0.1543 & 0.1168 & 0.08566 & 0.2948 \\
\hline & & {$[0.0726]$} & {$[0.230]$} & {$[0.216]$} & {$[0.285]$} & [0.291] & [0.0969] & {$[0.392]$} \\
\hline \multirow[t]{2}{*}{ Log GNI per capita 2006} & 0.1250 & $0.1471^{\mathrm{c}}$ & 0.1521 & 0.2179 & $0.2023^{c}$ & $0.2073^{\mathrm{c}}$ & 0.2016 & $0.2867^{\mathrm{b}}$ \\
\hline & {$[0.0772]$} & [0.0789] & {$[0.114]$} & {$[0.144]$} & {$[0.106]$} & [0.112] & {$[0.213]$} & {$[0.128]$} \\
\hline \multirow[t]{2}{*}{ Publicly available } & 0.06368 & -0.1103 & -0.00792 & -0.01167 & 0.05475 & 0.1328 & -0.2778 & 0.1115 \\
\hline & {$[0.225]$} & [0.299] & {$[0.287]$} & {$[0.296]$} & {$[0.341]$} & [0.269] & {$[0.423]$} & {$[0.418]$} \\
\hline \multirow[t]{2}{*}{ Constant } & $1.0990^{\mathrm{b}}$ & 0.8170 & 0.8755 & 0.4456 & 0.5867 & 0.3605 & 0.5352 & -0.2892 \\
\hline & {$[0.546]$} & {$[0.584]$} & {$[0.736]$} & {$[0.960]$} & {$[0.736]$} & {$[0.828]$} & [1.325] & [0.999] \\
\hline Observations & 63 & 63 & 55 & 38 & 39 & 39 & 21 & 27 \\
\hline R-squared & 0.08 & 0.10 & 0.09 & 0.13 & 0.20 & 0.19 & 0.30 & 0.31 \\
\hline
\end{tabular}

Panel C: Tests for the equality of public availability across groups

$\begin{array}{lcccccccc}\text { F-Statistic } & 2.08 & 2.98 & 2.01 & 1.42 & 0.82 & 0.64 & 3.17 & 1.07 \\ \text { Prob }>\text { F } & 0.1521 & 0.0869 & 0.1595 & 0.2358 & 0.3668 & 0.4247 & 0.0798 & 0.3046\end{array}$

Robust standard errors in brackets

Significance levels: (a) if $\mathrm{p}<0.01$; (b) if $\mathrm{p}<0.05$; (c.) if $\mathrm{p}<0.10$. 
Table 9: Perceived corruption and sources publicly available: the role of democracy.

\begin{tabular}{|c|c|c|c|c|c|c|c|c|}
\hline \multicolumn{9}{|c|}{ Dependent variable in all regressions is: ICRG corruption index (2003-2007) } \\
\hline \multicolumn{2}{|l|}{ Additional control variable is: } & $\begin{array}{l}\text { Democracy } \\
(1975-2006)\end{array}$ & $\begin{array}{c}\text { Proportional } \\
\text { representation } \\
(1975-2006)\end{array}$ & $\begin{array}{c}\text { Party vs } \\
\text { candidate- } \\
\text { specific voting }\end{array}$ & $\begin{array}{c}\text { Government } \\
\text { owned press } \\
(\%) \\
\end{array}$ & $\begin{array}{c}\text { Government } \\
\text { owned TV } \\
(\%) \\
\end{array}$ & $\begin{array}{l}\text { Newspaper } \\
\text { circulation }\end{array}$ & $\begin{array}{c}\text { Judicial } \\
\text { independence }\end{array}$ \\
\hline & \multicolumn{8}{|c|}{ Panel A: Above the mean democracy (1975-2006) score } \\
\hline \multirow[t]{2}{*}{ Additional control variable } & & 0.0469 & 0.0905 & 0.1356 & 1.3542 & 0.5277 & 0.2317 & $0.9752^{\mathrm{c}}$ \\
\hline & & {$[0.0568]$} & {$[0.2180]$} & {$[0.1433]$} & {$[1.4110]$} & {$[0.4394]$} & {$[0.1681]$} & {$[0.5610]$} \\
\hline \multirow[t]{2}{*}{ Log GNI percapita 2006} & $0.6931^{\mathrm{a}}$ & $0.6439^{\mathrm{a}}$ & $0.6873^{\mathrm{a}}$ & $0.6787^{\mathrm{a}}$ & $0.7883^{\mathrm{a}}$ & $0.7176^{\mathrm{a}}$ & $0.5703^{\mathrm{a}}$ & $0.6641^{\mathrm{a}}$ \\
\hline & {$[0.0782]$} & [0.0959] & [0.0792] & [0.0819] & {$[0.1343]$} & [0.1029] & [0.1497] & {$[0.1228]$} \\
\hline \multirow[t]{2}{*}{ Sources publicly available } & $0.7483^{\mathrm{b}}$ & $0.7585^{\mathrm{b}}$ & $0.7592^{\mathrm{b}}$ & $0.6425^{\mathrm{c}}$ & $0.6959^{\mathrm{c}}$ & $0.6997^{\mathrm{c}}$ & $0.8464^{\mathrm{b}}$ & $0.8357^{\mathrm{c}}$ \\
\hline & {$[0.3133]$} & {$[0.3154]$} & {$[0.3306]$} & {$[0.3322]$} & {$[0.3581]$} & {$[0.3641]$} & {$[0.3664]$} & {$[0.4542]$} \\
\hline \multirow[t]{2}{*}{ Constant } & $-3.5516^{\mathrm{a}}$ & $-3.4815^{\mathrm{a}}$ & $-3.5685^{\mathrm{a}}$ & $-3.4632^{a}$ & $-4.4641^{\mathrm{a}}$ & $-3.9901^{\mathrm{a}}$ & $-3.5062^{\mathrm{a}}$ & $-3.9721^{a}$ \\
\hline & {$[0.6747]$} & {$[0.6765]$} & {$[0.6823]$} & {$[0.7094]$} & {$[1.2690]$} & {$[0.8815]$} & {$[0.8200]$} & [1.2914] \\
\hline Observations & 65 & 65 & 64 & 60 & 47 & 47 & 52 & 39 \\
\hline \multirow[t]{2}{*}{ R-squared } & 0.65 & 0.65 & 0.65 & 0.64 & 0.64 & 0.65 & 0.67 & 0.66 \\
\hline & \multicolumn{8}{|c|}{ Panel B: Below the mean democracy (1975-2006) score } \\
\hline \multirow[t]{2}{*}{ Additional control variable } & & 0.0804 & 0.1004 & 0.0545 & -0.1062 & 0.1599 & 0.0664 & 0.2244 \\
\hline & & {$[0.0755]$} & [0.2339] & {$[0.2173]$} & {$[0.2513]$} & {$[0.2850]$} & [0.0982] & [0.3837] \\
\hline \multirow[t]{2}{*}{ Log GNI per capita 2006} & 0.1200 & $0.1392^{\mathrm{c}}$ & 0.1433 & 0.2109 & $0.1920^{\mathrm{c}}$ & $0.1947^{\mathrm{c}}$ & 0.2240 & $0.2790^{\mathrm{b}}$ \\
\hline & {$[0.0762]$} & {$[0.0783]$} & [0.1102] & {$[0.1474]$} & {$[0.1063]$} & [0.1104] & {$[0.2358]$} & [0.1314] \\
\hline \multirow[t]{2}{*}{ Sources publicly available } & 0.3263 & -0.0306 & 0.1895 & 0.1074 & 0.5572 & 0.6800 & -0.3490 & 1.0057 \\
\hline & {$[0.4934]$} & [0.6898] & {$[0.6178]$} & {$[0.6462]$} & [0.6094] & {$[0.5033]$} & {$[0.7656]$} & [1.1158] \\
\hline \multirow[t]{2}{*}{ Constant } & $1.1253^{\mathrm{b}}$ & 0.8757 & 0.9307 & 0.4808 & 0.6071 & 0.3922 & 0.3982 & -0.2157 \\
\hline & {$[0.5418]$} & {$[0.5850]$} & {$[0.7204]$} & {$[0.9833]$} & {$[0.7490]$} & {$[0.8281]$} & {$[1.4638]$} & [1.0229] \\
\hline Observations & 63 & 63 & 55 & 38 & 39 & 39 & 21 & 27 \\
\hline \multirow[t]{2}{*}{ R-squared } & 0.08 & 0.10 & 0.09 & 0.13 & 0.22 & 0.22 & 0.28 & 0.33 \\
\hline & \multicolumn{8}{|c|}{ Panel C: Tests for the equality of sources publicly available across groups } \\
\hline F-Statistic & 0.52 & 1.08 & 0.66 & 0.55 & 0.04 & 0.00 & 2.13 & 0.02 \\
\hline Prob $>$ F & 0.4716 & 0.3001 & 0.4171 & 0.4594 & 0.8445 & 0.9748 & 0.1496 & 0.8869 \\
\hline \multicolumn{9}{|c|}{$\begin{array}{l}\text { Robust standard errors in brackets } \\
\text { Significance levels: (a) if } \mathrm{p}<0.01 \text {; (b) if } \mathrm{p}<0.05 \text {; (c.) if } \mathrm{p}<0.10 \text {. }\end{array}$} \\
\hline
\end{tabular}


Table 10: Other corruption measures and disclosure indices

\begin{tabular}{|c|c|c|c|c|c|c|c|c|c|c|}
\hline Dependent variable is: & $\begin{array}{c}\text { Kaufmann } \\
\text { corruption } \\
\text { index } \\
(2003-2005) \\
\end{array}$ & $\begin{array}{l}\text { Transparency } \\
\text { International } \\
\text { corruption } \\
\text { index (2003. } \\
\text { 2007) }\end{array}$ & $\begin{array}{c}\text { Heritage } \\
\text { Foundation } \\
\text { corruption } \\
\text { index } \\
(2003-2007)\end{array}$ & $\begin{array}{c}\text { GCR } \\
\text { corruption } \\
\text { index } \\
(2003-2007)\end{array}$ & $\begin{array}{c}\text { Firms that } \\
\text { pay bribes } \\
(\%)\end{array}$ & $\begin{array}{c}\text { Kaufmann } \\
\text { corruption } \\
\text { index } \\
(2003-2005)\end{array}$ & $\begin{array}{l}\text { Transparency } \\
\text { International } \\
\text { corruption } \\
\text { index (2003. } \\
\text { 2007) }\end{array}$ & $\begin{array}{c}\text { Heritage } \\
\text { Foundation } \\
\text { corruption } \\
\text { index } \\
(2003-2007)\end{array}$ & $\begin{array}{c}\text { GCR } \\
\text { corruption } \\
\text { index } \\
(2003-2007)\end{array}$ & $\begin{array}{c}\text { Firms that } \\
\text { pay bribes } \\
(\%)\end{array}$ \\
\hline & \multicolumn{10}{|c|}{ Panel A: Full sample } \\
\hline Democracy (1975-2006) & $\begin{array}{c}0.0248 \\
{[0.0157]}\end{array}$ & $\begin{array}{l}0.0614^{\mathrm{c}} \\
{[0.0329]}\end{array}$ & $\begin{array}{c}0.3956 \\
{[0.3571]}\end{array}$ & $\begin{array}{c}0.0326 \\
{[0.0220]}\end{array}$ & $\begin{array}{l}-1.3651 \\
{[1.0473]}\end{array}$ & $\begin{array}{c}0.0210 \\
{[0.0160]}\end{array}$ & $\begin{array}{c}0.0552 \\
{[0.0338]}\end{array}$ & $\begin{array}{c}0.3116 \\
{[0.3682]}\end{array}$ & $\begin{array}{c}0.0300 \\
{[0.0225]}\end{array}$ & $\begin{array}{l}-1.3719 \\
{[1.0304]}\end{array}$ \\
\hline Log GNI per capita 2006 & $\begin{array}{c}0.4538^{\mathrm{a}} \\
{[0.0371]}\end{array}$ & $\begin{array}{c}0.9182^{\mathrm{a}} \\
{[0.0818]}\end{array}$ & $\begin{array}{c}10.558^{\mathrm{a}} \\
{[0.8631]}\end{array}$ & $\begin{array}{c}0.4654^{\mathrm{a}} \\
{[0.0524]}\end{array}$ & $\begin{array}{l}-6.6046^{\mathrm{a}} \\
{[2.1621]}\end{array}$ & $\begin{array}{c}0.4472^{\mathrm{a}} \\
{[0.0372]}\end{array}$ & $\begin{array}{l}0.9084^{\mathrm{a}} \\
{[0.0819]}\end{array}$ & $\begin{array}{l}10.4341^{\mathrm{a}} \\
{[0.8664]}\end{array}$ & $\begin{array}{c}0.4611^{\mathrm{a}} \\
{[0.0525]}\end{array}$ & $\begin{array}{l}-6.4850^{\mathrm{a}} \\
{[2.2517]}\end{array}$ \\
\hline Publicly available & $\begin{array}{c}0.1318 \\
{[0.1130]}\end{array}$ & $\begin{array}{c}0.3306 \\
{[0.2560]}\end{array}$ & $\begin{array}{c}1.4824 \\
{[2.6212]}\end{array}$ & $\begin{array}{c}0.0082 \\
{[0.1410]}\end{array}$ & $\begin{array}{l}-2.1789 \\
{[4.4932]}\end{array}$ & & & & & \\
\hline Sources publicly available & & & & & & $\begin{array}{c}0.3875^{\mathrm{c}} \\
{[0.2113]}\end{array}$ & $\begin{array}{c}0.8244 \\
{[0.5163]}\end{array}$ & $\begin{array}{c}5.6964 \\
{[5.2314]}\end{array}$ & $\begin{array}{c}0.1123 \\
{[0.2690]}\end{array}$ & $\begin{array}{l}-4.8379 \\
{[9.4050]}\end{array}$ \\
\hline Constant & $\begin{array}{l}-3.8262^{\mathrm{a}} \\
{[0.2500]}\end{array}$ & $\begin{array}{l}-3.6879^{\mathrm{a}} \\
{[0.5390]}\end{array}$ & $\begin{array}{c}-47.1291^{\mathrm{a}} \\
{[5.880]}\end{array}$ & $\begin{array}{c}0.2710 \\
{[0.3780]}\end{array}$ & $\begin{array}{c}94.8891^{\mathrm{a}} \\
{[14.7501]}\end{array}$ & $\begin{array}{l}-3.7764^{\mathrm{a}} \\
{[0.2526]}\end{array}$ & $\begin{array}{l}-3.6084^{\mathrm{a}} \\
{[0.5438]}\end{array}$ & $\begin{array}{c}-46.2179^{\mathrm{a}} \\
{[5.9254]}\end{array}$ & $\begin{array}{c}0.3004 \\
{[0.3813]}\end{array}$ & $\begin{array}{c}94.0698^{\mathrm{a}} \\
{[15.2798]}\end{array}$ \\
\hline $\begin{array}{l}\text { Observations } \\
\text { R-squared }\end{array}$ & $\begin{array}{l}152 \\
0.71\end{array}$ & $\begin{array}{l}152 \\
0.71\end{array}$ & $\begin{array}{c}141 \\
0.72\end{array}$ & $\begin{array}{r}126 \\
0.59\end{array}$ & $\begin{array}{c}77 \\
0.28\end{array}$ & $\begin{array}{r}152 \\
0.72\end{array}$ & $\begin{array}{l}152 \\
0.71\end{array}$ & $\begin{array}{c}141 \\
0.72\end{array}$ & $\begin{array}{c}126 \\
0.59\end{array}$ & $\begin{array}{c}77 \\
0.28\end{array}$ \\
\hline & \multicolumn{10}{|c|}{ Panel B: Subsample of countries with high democracy scores (above the mean democracy (1975-2006)) } \\
\hline Democracy (1975-2006) & $\begin{array}{c}0.0729^{c} \\
{[0.0390]}\end{array}$ & $\begin{array}{c}0.1647^{\mathrm{c}} \\
{[0.0915]}\end{array}$ & $\begin{array}{c}0.7824 \\
{[1.1750]}\end{array}$ & $\begin{array}{c}0.0772 \\
{[0.0601]}\end{array}$ & $\begin{array}{c}2.8567 \\
{[2.2591]}\end{array}$ & $\begin{array}{c}0.0699^{c} \\
{[0.0390]}\end{array}$ & $\begin{array}{c}0.1566^{\mathrm{c}} \\
{[0.0924]}\end{array}$ & $\begin{array}{c}0.7595 \\
{[1.1819]}\end{array}$ & $\begin{array}{c}0.0755 \\
{[0.0606]}\end{array}$ & $\begin{array}{c}2.8125 \\
{[2.3642]}\end{array}$ \\
\hline Log GNI per capita 2006 & $\begin{array}{c}0.5994^{\mathrm{a}} \\
{[0.0525]}\end{array}$ & $\begin{array}{c}1.2827^{\mathrm{a}} \\
{[0.1172]}\end{array}$ & $\begin{array}{c}14.565^{\mathrm{a}} \\
{[1.7081]}\end{array}$ & $\begin{array}{c}0.5594^{\mathrm{a}} \\
{[0.0910]}\end{array}$ & $\begin{array}{l}-5.9726 \\
{[6.1532]}\end{array}$ & $\begin{array}{c}0.5969^{\mathrm{a}} \\
{[0.0539]}\end{array}$ & $\begin{array}{c}1.2871^{\mathrm{a}} \\
{[0.1206]}\end{array}$ & $\begin{array}{l}14.3938^{\mathrm{a}} \\
{[1.7208]}\end{array}$ & $\begin{array}{c}0.5530^{\mathrm{a}} \\
{[0.0914]}\end{array}$ & $\begin{array}{l}-5.1198 \\
{[6.5926]}\end{array}$ \\
\hline Publicly available & $\begin{array}{c}0.2790^{\mathrm{b}} \\
{[0.1251]}\end{array}$ & $\begin{array}{l}0.6233 b \\
{[0.2900]}\end{array}$ & $\begin{array}{c}4.8038 \\
{[3.2692]}\end{array}$ & $\begin{array}{c}0.2728^{\mathrm{c}} \\
{[0.1551]}\end{array}$ & $\begin{array}{c}-5.0690 \\
{[5.3660]}\end{array}$ & & & & & \\
\hline Sources publicly available & & & & & & $\begin{array}{c}0.4979^{\mathrm{b}} \\
{[0.1939]}\end{array}$ & $\begin{array}{c}1.0183^{b} \\
{[0.4779]}\end{array}$ & $\begin{array}{c}9.3849^{c} \\
{[5.1102]}\end{array}$ & $\begin{array}{c}0.5027^{\mathrm{b}} \\
{[0.2475]}\end{array}$ & $\begin{array}{l}-11.2415 \\
{[10.3019]}\end{array}$ \\
\hline Constant & $\begin{array}{l}-5.6441^{\mathrm{a}} \\
{[0.3331]}\end{array}$ & $\begin{array}{l}-8.0503^{\mathrm{a}} \\
{[0.7194]}\end{array}$ & $\begin{array}{c}-89.5812^{\mathrm{a}} \\
{[9.8883]}\end{array}$ & $\begin{array}{l}-1.1365^{\mathrm{b}} \\
{[0.4972]}\end{array}$ & $\begin{array}{c}60.4171 \\
{[42.8801]}\end{array}$ & $\begin{array}{l}-5.5886^{\mathrm{a}} \\
{[0.3433]}\end{array}$ & $\begin{array}{l}-7.9781^{\mathrm{a}} \\
{[0.7539]}\end{array}$ & $\begin{array}{l}-87.9100^{\mathrm{a}} \\
{[10.0478]}\end{array}$ & $\begin{array}{l}-1.0606^{b} \\
{[0.4954]}\end{array}$ & $\begin{array}{c}53.9245 \\
{[44.4919]}\end{array}$ \\
\hline Observations & 71 & 71 & 68 & 68 & 35 & 71 & 71 & 68 & 68 & 35 \\
\hline R-squared & 0.82 & 0.79 & 0.75 & 0.72 & 0.12 & 0.82 & 0.79 & 0.76 & 0.72 & 0.13 \\
\hline $\begin{array}{l}\text { Robust standard errors in bra } \\
\text { Significance levels: (a) if } \mathrm{p}<0\end{array}$ & $\begin{array}{l}\text { ackets } \\
0.01 ;(\mathrm{b}) \text { if } \mathrm{p}<0\end{array}$ & 0.05 ; (c.) if $\mathrm{p}<0.1$ & & & & & & & & \\
\hline
\end{tabular}


Table 11: All corruption measures, disclosure indices and religion

\begin{tabular}{|c|c|c|c|c|c|c|c|c|c|c|c|c|}
\hline Dependent variable is: & $\begin{array}{c}\text { ICRG } \\
\text { corruption } \\
\text { index } \\
(2003-2007)\end{array}$ & $\begin{array}{c}\text { Kaufmann } \\
\text { corruption } \\
\text { index } \\
(2003-2005)\end{array}$ & $\begin{array}{l}\text { Transparency } \\
\text { International } \\
\text { corruption } \\
\text { index } \\
(2003-2007)\end{array}$ & $\begin{array}{c}\text { Heritage } \\
\text { Foundation } \\
\text { corruption } \\
\text { index } \\
(2003-2007)\end{array}$ & $\begin{array}{c}\text { GCR } \\
\text { corruption } \\
\text { index } \\
(2003-2007)\end{array}$ & $\begin{array}{c}\text { Firms that } \\
\text { pay bribes } \\
(\%)\end{array}$ & $\begin{array}{c}\text { ICRG } \\
\text { corruption } \\
\text { index } \\
(2003-2007)\end{array}$ & $\begin{array}{c}\text { Kaufmann } \\
\text { corruption } \\
\text { index } \\
(2003-2005)\end{array}$ & $\begin{array}{l}\text { Transparency } \\
\text { International } \\
\text { corruption } \\
\text { index } \\
(2003-2007)\end{array}$ & $\begin{array}{c}\text { Heritage } \\
\text { Foundation } \\
\text { corruption } \\
\text { index } \\
(2003-2007)\end{array}$ & $\begin{array}{c}\text { GCR } \\
\text { corruption } \\
\text { index } \\
(2003-2007)\end{array}$ & $\begin{array}{c}\text { Firms that } \\
\text { pay bribes } \\
(\%)\end{array}$ \\
\hline & \multicolumn{12}{|c|}{ Panel A: Full sample } \\
\hline Democracy (1975-2006) & $\begin{array}{c}0.0422 \\
{[0.0275]}\end{array}$ & $\begin{array}{c}0.0125 \\
{[0.0171]}\end{array}$ & $\begin{array}{c}0.0267 \\
{[0.0356]}\end{array}$ & $\begin{array}{c}0.1866 \\
{[0.3649]}\end{array}$ & $\begin{array}{c}0.0173 \\
{[0.0229]}\end{array}$ & $\begin{array}{l}-1.3854 \\
{[1.0612]}\end{array}$ & $\begin{array}{c}0.0394 \\
{[0.0269]}\end{array}$ & $\begin{array}{c}0.0100 \\
{[0.0171]}\end{array}$ & $\begin{array}{c}0.0238 \\
{[0.0359]}\end{array}$ & $\begin{array}{c}0.1514 \\
{[0.3673]}\end{array}$ & $\begin{array}{c}0.0159 \\
{[0.0231]}\end{array}$ & $\begin{array}{l}-1.4090 \\
{[1.0413]}\end{array}$ \\
\hline Log GNI per capita 2006 & $\begin{array}{c}0.3057^{\mathrm{a}} \\
{[0.0601]}\end{array}$ & $\begin{array}{c}0.4599^{\mathrm{a}} \\
{[0.0374]}\end{array}$ & $\begin{array}{c}0.9250^{\mathrm{a}} \\
{[0.0814]}\end{array}$ & $\begin{array}{l}10.1067^{\mathrm{a}} \\
{[0.8365]}\end{array}$ & $\begin{array}{c}0.4477^{\mathrm{a}} \\
{[0.0522]}\end{array}$ & $\begin{array}{l}-6.4138^{\mathrm{a}} \\
{[2.1377]}\end{array}$ & $\begin{array}{c}0.2985^{\mathrm{a}} \\
{[0.0612]}\end{array}$ & $\begin{array}{c}0.4540^{\mathrm{a}} \\
{[0.0376]}\end{array}$ & $\begin{array}{c}0.9178^{\mathrm{a}} \\
{[0.0816]}\end{array}$ & $\begin{array}{l}10.0425^{\mathrm{a}} \\
{[0.8424]}\end{array}$ & $\begin{array}{c}0.4448^{\mathrm{a}} \\
{[0.0523]}\end{array}$ & $\begin{array}{l}-6.1322^{\mathrm{a}} \\
{[2.2259]}\end{array}$ \\
\hline Publicly available & $\begin{array}{l}0.2953^{\mathrm{c}} \\
{[0.1770]}\end{array}$ & $\begin{array}{c}0.1032 \\
{[0.1073]}\end{array}$ & $\begin{array}{c}0.2487 \\
{[0.2389]}\end{array}$ & $\begin{array}{c}1.2681 \\
{[2.4156]}\end{array}$ & $\begin{array}{l}-0.0592 \\
{[0.1381]}\end{array}$ & $\begin{array}{l}-3.6666 \\
{[4.4142]}\end{array}$ & & & & & & \\
\hline Sources publicly available & & & & & & & $\begin{array}{l}0.6861^{\mathrm{b}} \\
{[0.3253]}\end{array}$ & $\begin{array}{c}0.3148 \\
{[0.2061]}\end{array}$ & $\begin{array}{c}0.6099 \\
{[0.4957]}\end{array}$ & $\begin{array}{c}3.9013 \\
{[5.0375]}\end{array}$ & $\begin{array}{l}-0.0368 \\
{[0.2649]}\end{array}$ & $\begin{array}{l}-9.2700 \\
{[8.8110]}\end{array}$ \\
\hline Protestant population & $\begin{array}{l}0.0143^{\mathrm{a}} \\
{[0.0045]}\end{array}$ & $\begin{array}{l}0.0083^{\mathrm{a}} \\
{[0.0020]}\end{array}$ & $\begin{array}{c}0.0230^{\mathrm{a}} \\
{[0.0043]}\end{array}$ & $\begin{array}{c}0.2452^{\mathrm{a}} \\
{[0.0434]}\end{array}$ & $\begin{array}{c}0.0130^{\mathrm{a}} \\
{[0.0024]}\end{array}$ & $\begin{array}{l}-0.2655^{\mathrm{b}} \\
{[0.1151]}\end{array}$ & $\begin{array}{l}0.0136^{\mathrm{a}} \\
{[0.0046]}\end{array}$ & $\begin{array}{l}0.0079^{\mathrm{a}} \\
{[0.0020]}\end{array}$ & $\begin{array}{l}0.0225^{\mathrm{a}} \\
{[0.0044]}\end{array}$ & $\begin{array}{c}0.2408^{\mathrm{a}} \\
{[0.0444]}\end{array}$ & $\begin{array}{l}0.0129^{\mathrm{a}} \\
{[0.0024]}\end{array}$ & $\begin{array}{l}-0.2632^{b} \\
{[0.1128]}\end{array}$ \\
\hline Constant & $\begin{array}{c}-0.4704 \\
{[0.4207]}\end{array}$ & $\begin{array}{l}-3.9105^{\mathrm{a}} \\
{[0.2457]}\end{array}$ & $\begin{array}{l}-3.8294^{\mathrm{a}} \\
{[0.5178]}\end{array}$ & $\begin{array}{l}-44.9456^{\mathrm{a}} \\
{[5.4251]}\end{array}$ & $\begin{array}{c}0.3813 \\
{[0.3673]}\end{array}$ & $\begin{array}{c}95.8150^{\mathrm{a}} \\
{[14.4944]}\end{array}$ & $\begin{array}{l}-0.4064 \\
{[0.4313]}\end{array}$ & $\begin{array}{l}-3.8666^{\mathrm{a}} \\
{[0.2489]}\end{array}$ & $\begin{array}{l}-3.7700^{\mathrm{a}} \\
{[0.5240]}\end{array}$ & $\begin{array}{l}-44.4445^{\mathrm{c}} \\
{[5.4941]}\end{array}$ & $\begin{array}{c}0.3970 \\
{[0.3700]}\end{array}$ & $\begin{array}{c}93.9890^{\mathrm{a}} \\
{[15.0070]}\end{array}$ \\
\hline $\begin{array}{l}\text { Observations } \\
\text { R-squared }\end{array}$ & $\begin{array}{c}127 \\
0.56\end{array}$ & $\begin{array}{c}149 \\
0.74\end{array}$ & $\begin{array}{l}149 \\
0.75\end{array}$ & $\begin{array}{l}139 \\
0.77\end{array}$ & $\begin{array}{c}123 \\
0.64\end{array}$ & $\begin{array}{c}76 \\
0.33\end{array}$ & $\begin{array}{c}127 \\
0.56\end{array}$ & $\begin{array}{l}149 \\
0.75\end{array}$ & $\begin{array}{c}149 \\
0.75\end{array}$ & $\begin{array}{c}139 \\
0.77\end{array}$ & $\begin{array}{c}123 \\
0.64\end{array}$ & $\begin{array}{c}76 \\
0.33\end{array}$ \\
\hline & \multicolumn{12}{|c|}{ Panel B: Subsample of countries with high democracy scores (above the mean democracy (1975-2006)) } \\
\hline Democracy (1975-2006) & $\begin{array}{c}0.0336 \\
{[0.0641]}\end{array}$ & $\begin{array}{c}0.0539 \\
{[0.0419]}\end{array}$ & $\begin{array}{c}0.1081 \\
{[0.0948]}\end{array}$ & $\begin{array}{c}1.0005 \\
{[1.1442]}\end{array}$ & $\begin{array}{c}0.0751 \\
{[0.0612]}\end{array}$ & $\begin{array}{c}2.6548 \\
{[2.3176]}\end{array}$ & $\begin{array}{c}0.0301 \\
{[0.0645]}\end{array}$ & $\begin{array}{c}0.0535 \\
{[0.0416]}\end{array}$ & $\begin{array}{c}0.1044 \\
{[0.0952]}\end{array}$ & $\begin{array}{c}0.9989 \\
{[1.1508]}\end{array}$ & $\begin{array}{c}0.0763 \\
{[0.0610]}\end{array}$ & $\begin{array}{c}2.3870 \\
{[2.4563]}\end{array}$ \\
\hline Log GNI per capita 2006 & $\begin{array}{c}0.5942^{\mathrm{a}} \\
{[0.0993]}\end{array}$ & $\begin{array}{c}0.5914^{\mathrm{a}} \\
{[0.0558]}\end{array}$ & $\begin{array}{c}1.2530^{\mathrm{a}} \\
{[0.1210]}\end{array}$ & $\begin{array}{l}12.4131^{\mathrm{a}} \\
{[1.5973]}\end{array}$ & $\begin{array}{c}0.4880^{\mathrm{a}} \\
{[0.0967]}\end{array}$ & $\begin{array}{l}-4.2632 \\
{[6.3143]}\end{array}$ & $\begin{array}{c}0.5958^{\mathrm{a}} \\
{[0.1075]}\end{array}$ & $\begin{array}{c}0.5869^{\mathrm{a}} \\
{[0.0571]}\end{array}$ & $\begin{array}{c}1.2538^{\mathrm{a}} \\
{[0.1242]}\end{array}$ & $\begin{array}{l}12.3092^{\mathrm{a}} \\
{[1.6490]}\end{array}$ & $\begin{array}{c}0.4789^{\mathrm{a}} \\
{[0.0960]}\end{array}$ & $\begin{array}{l}-2.9703 \\
{[6.8355]}\end{array}$ \\
\hline Publicly available & $\begin{array}{l}0.4465^{\mathrm{b}} \\
{[0.1897]}\end{array}$ & $\begin{array}{l}0.2551^{\mathrm{b}} \\
{[0.1192]}\end{array}$ & $\begin{array}{l}0.5350 \mathrm{c} \\
{[0.2726]}\end{array}$ & $\begin{array}{l}4.8884^{\mathrm{c}} \\
{[2.9222]}\end{array}$ & $\begin{array}{c}0.2132 \\
{[0.1569]}\end{array}$ & $\begin{array}{l}-6.3484 \\
{[5.0218]}\end{array}$ & & & & & & \\
\hline Sources publicly available & & & & & & & $\begin{array}{c}0.7037^{\mathrm{b}} \\
{[0.3086]}\end{array}$ & $\begin{array}{c}0.4658^{\mathrm{b}} \\
{[0.1875]}\end{array}$ & $\begin{array}{c}0.8784^{\mathrm{c}} \\
{[0.4646]}\end{array}$ & $\begin{array}{c}8.8280^{\mathrm{c}} \\
{[4.9832]}\end{array}$ & $\begin{array}{c}0.4333^{\mathrm{c}} \\
{[0.2428]}\end{array}$ & $\begin{array}{c}-16.3728^{\mathrm{c}} \\
{[9.0616]}\end{array}$ \\
\hline Protestant population & $\begin{array}{c}0.0098^{\mathrm{b}} \\
{[0.0041]}\end{array}$ & $\begin{array}{c}0.0066^{\mathrm{a}} \\
{[0.0017]}\end{array}$ & $\begin{array}{c}0.0188^{\mathrm{a}} \\
{[0.0037]}\end{array}$ & $\begin{array}{c}0.1968^{\mathrm{a}} \\
{[0.0435]}\end{array}$ & $\begin{array}{c}0.0098^{\mathrm{a}} \\
{[0.0020]}\end{array}$ & $\begin{array}{l}-0.2871^{\mathrm{b}} \\
{[0.1100]}\end{array}$ & $\begin{array}{c}0.0097^{\mathrm{b}} \\
{[0.0044]}\end{array}$ & $\begin{array}{c}0.0064^{\mathrm{a}} \\
{[0.0018]}\end{array}$ & $\begin{array}{c}0.0185^{\mathrm{a}} \\
{[0.0039]}\end{array}$ & $\begin{array}{c}0.1933^{\mathrm{a}} \\
{[0.0459]}\end{array}$ & $\begin{array}{c}0.0096^{\mathrm{a}} \\
{[0.0020]}\end{array}$ & $\begin{array}{l}-0.2899^{\mathrm{a}} \\
{[0.1050]}\end{array}$ \\
\hline Constant & $\begin{array}{l}-3.1026^{\mathrm{a}} \\
{[0.6642]}\end{array}$ & $\begin{array}{l}-5.5237^{\mathrm{a}} \\
{[0.3246]}\end{array}$ & $\begin{array}{l}-7.6049^{\mathrm{a}} \\
{[0.6851]}\end{array}$ & $\begin{array}{c}-74.4186^{\mathrm{a}} \\
{[8.6637]}\end{array}$ & $\begin{array}{c}-0.5857 \\
{[0.5248]}\end{array}$ & $\begin{array}{c}50.7958 \\
{[44.0582]}\end{array}$ & $\begin{array}{l}-3.0438^{\mathrm{a}} \\
{[0.7128]}\end{array}$ & $\begin{array}{l}-5.4688^{\mathrm{a}} \\
{[0.3330]}\end{array}$ & $\begin{array}{l}-7.5372^{\mathrm{a}} \\
{[0.7131]}\end{array}$ & $\begin{array}{c}-73.2395^{\mathrm{a}} \\
{[8.9236]}\end{array}$ & $\begin{array}{c}-0.5149 \\
{[0.5175]}\end{array}$ & $\begin{array}{c}42.6933 \\
{[45.6654]}\end{array}$ \\
\hline Observations & 64 & 69 & 69 & 66 & 65 & 34 & 64 & 69 & 69 & 66 & 65 & 34 \\
\hline R-squared & 0.70 & 0.84 & 0.83 & 0.81 & 0.76 & 0.20 & 0.70 & 0.84 & 0.83 & 0.81 & 0.77 & 0.22 \\
\hline $\begin{array}{l}\text { Robust standard errors in bra } \\
\text { Significance levels: (a) if } p<0\end{array}$ & $\begin{array}{l}\text { ckets } \\
.01 ;(b) \text { if } \mathrm{p}<1\end{array}$ & 5 ; (c.) if $\mathrm{p}<$ & & & & & & & & & & \\
\hline
\end{tabular}




\section{Figures 1 and 2}

Scatter plots of the form content disclosure indices for the full sample of 175 countries.
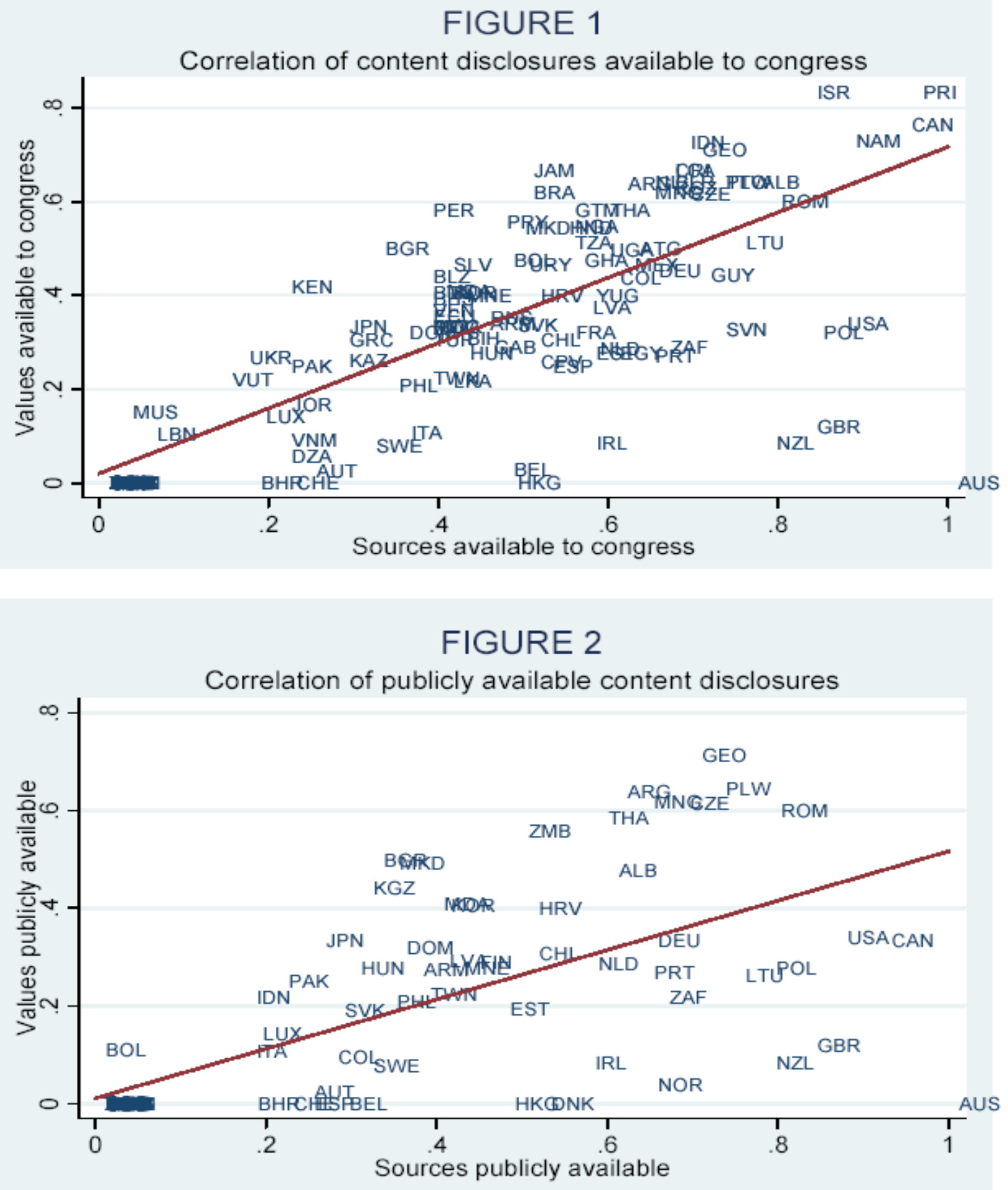


\section{Figures 3 and 4}

Partial scatter plots of publicly available and the ICRG corruption index (2003-2007) for the subsamples of countries above (Figure 3) and below (Figure 4) the mean value of the democracy score (1975-2006) of our sample of 175 countries. The dependent variable is the ICRG corruption index (2003-2007). In addition to publicly available, each regression controls for the log of GNI per capita 2006 and democracy (1975-2006).

\section{FIGURE 3}

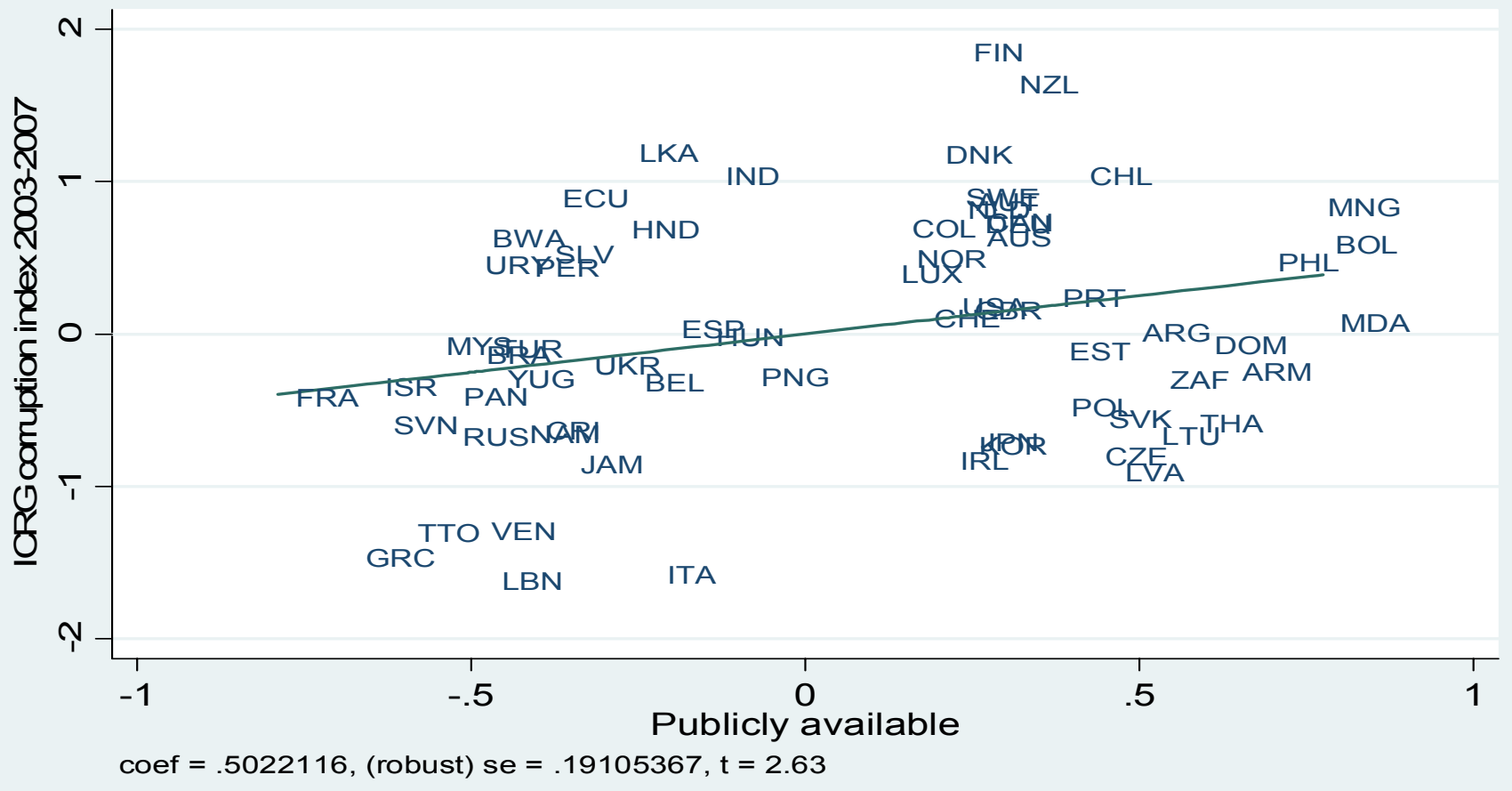

\section{FIGURE 4}

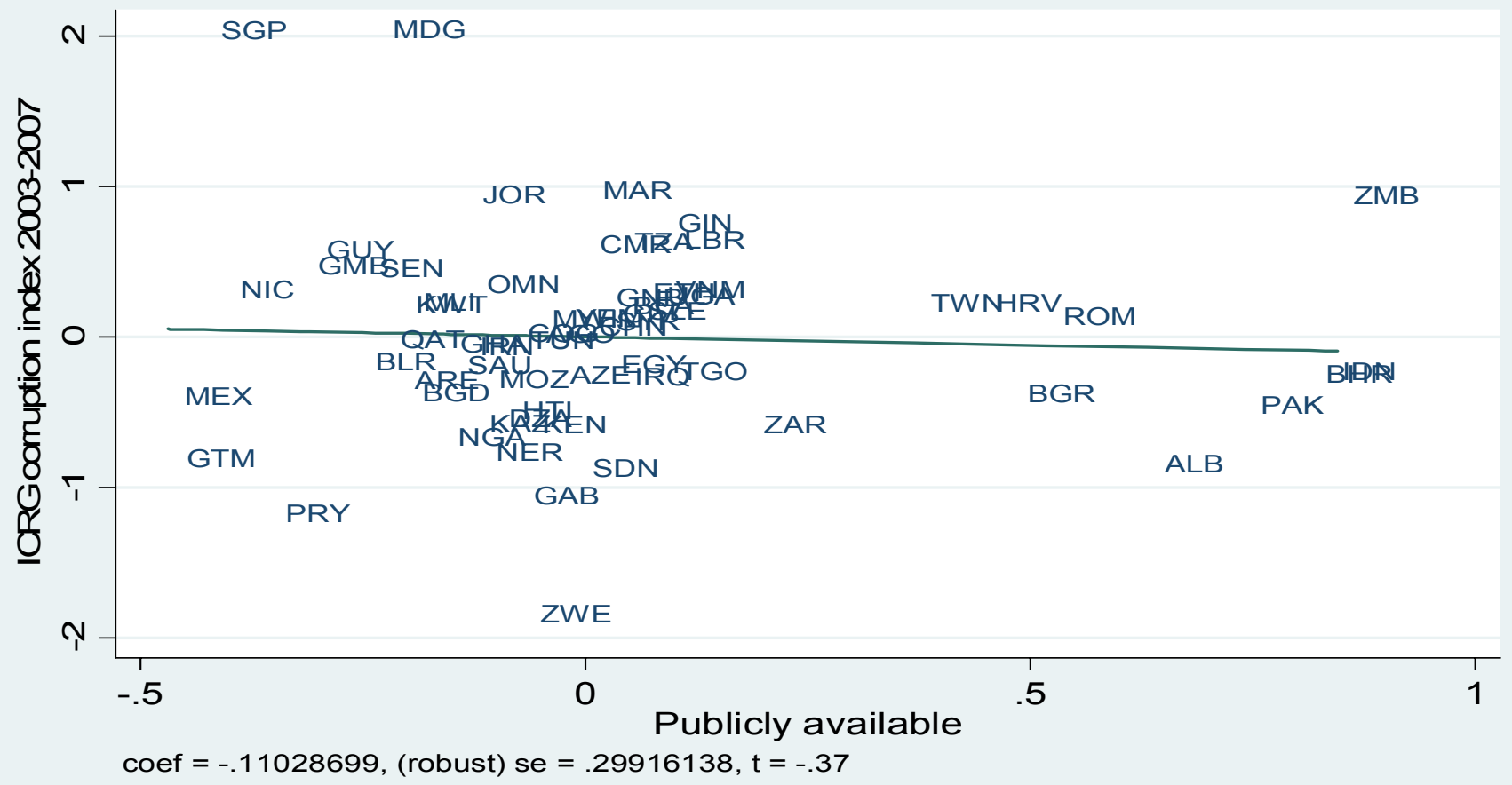


Appendix A: Disclosure and enforcement indices by income groups

\begin{tabular}{|c|c|c|c|c|c|c|c|c|}
\hline \multirow[b]{2}{*}{ Country } & \multicolumn{2}{|c|}{$\begin{array}{l}\text { Requirements and } \\
\text { public availability }\end{array}$} & \multicolumn{4}{|c|}{ Form content (based on universal form concept) } & \multicolumn{2}{|c|}{ Enforcement } \\
\hline & $\begin{array}{l}\text { Dsclosure } \\
\text { required }\end{array}$ & $\begin{array}{l}\text { Publicly } \\
\text { available }\end{array}$ & $\begin{array}{c}\text { Values } \\
\text { available to } \\
\text { congress }\end{array}$ & $\begin{array}{c}\text { Sources } \\
\text { available to } \\
\text { congress }\end{array}$ & $\begin{array}{c}\text { Values } \\
\text { publicly } \\
\text { available }\end{array}$ & $\begin{array}{l}\text { Sources } \\
\text { publicly } \\
\text { available }\end{array}$ & $\begin{array}{l}\text { Registrar } \\
\text { strength }\end{array}$ & $\begin{array}{l}\text { Checking } \\
\text { unit strength }\end{array}$ \\
\hline
\end{tabular}

Panel A: High income with publicly available disclosures

\begin{tabular}{|c|c|c|c|c|c|c|c|c|}
\hline Australia & 1.00 & 1.00 & 0.00 & 1.00 & 0.00 & 1.00 & 0.33 & 0.33 \\
\hline Austria & 1.00 & 1.00 & 0.02 & 0.24 & 0.02 & 0.24 & 0.00 & 0.00 \\
\hline Bahrain & 1.00 & 1.00 & 0.00 & 0.18 & 0.00 & 0.18 & 0.00 & 0.00 \\
\hline Belgium & 1.00 & 0.50 & 0.03 & 0.48 & 0.00 & 0.29 & 0.83 & 0.67 \\
\hline Canada & 1.00 & 1.00 & 0.76 & 0.94 & 0.33 & 0.92 & 0.00 & 0.00 \\
\hline Denmark & 0.00 & 1.00 & 0.00 & 0.00 & 0.00 & 0.52 & 0.00 & 0.00 \\
\hline Finland & 0.00 & 1.00 & 0.00 & 0.00 & 0.29 & 0.44 & 0.00 & 0.00 \\
\hline Germany & 1.00 & 1.00 & 0.45 & 0.65 & 0.33 & 0.65 & 0.67 & 0.33 \\
\hline Greece & 1.00 & 0.00 & 0.31 & 0.28 & 0.00 & 0.00 & 0.33 & 0.67 \\
\hline Hong Kong, China & 1.00 & 1.00 & 0.00 & 0.48 & 0.00 & 0.48 & 0.33 & 0.00 \\
\hline Ireland & 1.00 & 1.00 & 0.08 & 0.57 & 0.08 & 0.57 & 0.00 & 0.00 \\
\hline Italy & 1.00 & 0.50 & 0.11 & 0.36 & 0.11 & 0.18 & 0.33 & 0.00 \\
\hline Japan & 1.00 & 1.00 & 0.33 & 0.28 & 0.33 & 0.26 & 0.33 & 0.00 \\
\hline Korea & 1.00 & 1.00 & 0.40 & 0.40 & 0.40 & 0.40 & 0.00 & 0.17 \\
\hline Luxembourg & 1.00 & 1.00 & 0.14 & 0.18 & 0.14 & 0.18 & 0.00 & 0.00 \\
\hline Netherlands & 1.00 & 1.00 & 0.29 & 0.58 & 0.29 & 0.58 & 0.00 & 0.00 \\
\hline New Zealand & 1.00 & 1.00 & 0.08 & 0.79 & 0.08 & 0.79 & 0.33 & 0.33 \\
\hline Norway & 0.00 & 1.00 & 0.00 & 0.00 & 0.04 & 0.65 & 0.00 & 0.00 \\
\hline Portugal & 1.00 & 1.00 & 0.27 & 0.64 & 0.27 & 0.64 & 0.50 & 0.50 \\
\hline Spain & 1.00 & 0.50 & 0.25 & 0.52 & 0.00 & 0.24 & 0.17 & 0.33 \\
\hline Sweden & 1.00 & 1.00 & 0.08 & 0.31 & 0.08 & 0.31 & 0.33 & 0.00 \\
\hline Switzerland & 1.00 & 1.00 & 0.00 & 0.22 & 0.00 & 0.22 & 0.33 & 0.00 \\
\hline Taiwan, China & 1.00 & 1.00 & 0.22 & 0.38 & 0.22 & 0.38 & 1.00 & 0.67 \\
\hline United Kingdom & 1.00 & 1.00 & 0.12 & 0.83 & 0.12 & 0.83 & 0.00 & 0.00 \\
\hline United States & 1.00 & 1.00 & 0.34 & 0.87 & 0.34 & 0.87 & 0.33 & 0.33 \\
\hline Mean & 0.88 & 0.90 & 0.17 & 0.45 & 0.14 & 0.47 & 0.25 & 0.17 \\
\hline
\end{tabular}

Panel B: High income with disclosures available to congress

\begin{tabular}{lll|lllll|ll} 
Antigua and Barbuda & 1.00 & 0.00 & 0.50 & 0.63 & 0.00 & 0.00 & 1.00 & 0.33 \\
Bahamas & 1.00 & 0.00 & 0.39 & 0.38 & 0.00 & 0.00 & 0.67 & 0.67 \\
France & 1.00 & 0.00 & 0.32 & 0.55 & 0.00 & 0.00 & 0.67 & 0.33 \\
Israel & 1.00 & 0.00 & 0.83 & 0.83 & 0.00 & 0.00 & 0.33 & 0.00 \\
Puerto Rico & 1.00 & 0.00 & 0.83 & 0.96 & 0.00 & 0.00 & 0.67 & 0.67 \\
Singapore & 0.00 & 0.00 & 0.00 & 0.00 & 0.00 & 0.00 & 0.00 & 0.00 \\
Slovenia & 1.00 & 0.00 & 0.33 & 0.73 & 0.00 & 0.00 & 0.67 & 0.67 \\
Mean & $\mathbf{0 . 8 6}$ & $\mathbf{0 . 0 0}$ & $\mathbf{0 . 4 6}$ & $\mathbf{0 . 5 8}$ & $\mathbf{0 . 0 0}$ & $\mathbf{0 . 0 0}$ & $\mathbf{0 . 5 7}$ & $\mathbf{0 . 3 8}$ \\
\hline
\end{tabular}

Panel C: High income without disclosure requirements

\begin{tabular}{lll|lllllll} 
Brunei & 0.00 & 0.00 & 0.00 & 0.00 & 0.00 & 0.00 & 0.00 & 0.00 \\
Kuwait & 0.00 & 0.00 & 0.00 & 0.00 & 0.00 & 0.00 & 0.00 & 0.00 \\
Qatar & 0.00 & 0.00 & 0.00 & 0.00 & 0.00 & 0.00 & 0.00 & 0.00 \\
Saudi Arabia & 0.00 & 0.00 & 0.00 & 0.00 & 0.00 & 0.00 & 0.00 & 0.00 \\
United Arab Emirates & 0.00 & 0.00 & 0.00 & 0.00 & 0.00 & 0.00 & 0.00 & 0.00 \\
Mean & $\mathbf{0 . 0 0}$ & $\mathbf{0 . 0 0}$ & $\mathbf{0 . 0 0}$ & $\mathbf{0 . 0 0}$ & $\mathbf{0 . 0 0}$ & $\mathbf{0 . 0 0}$ & $\mathbf{0 . 0 0}$ & $\mathbf{0 . 0 0}$ \\
\hline
\end{tabular}

Panel D: Upper middle income with publicly available disclosures

\begin{tabular}{lll|llll|ll} 
Argentina & 1.00 & 1.00 & 0.64 & 0.61 & 0.64 & 0.61 & 0.00 & 0.00 \\
Chile & 1.00 & 1.00 & 0.31 & 0.51 & 0.31 & 0.51 & 0.33 & 0.33 \\
Croatia & 1.00 & 1.00 & 0.40 & 0.51 & 0.40 & 0.51 & 0.67 & 0.33 \\
Czech Republic & 1.00 & 1.00 & 0.62 & 0.68 & 0.62 & 0.68 & 0.33 & 0.33 \\
Estonia & 1.00 & 1.00 & 0.28 & 0.57 & 0.19 & 0.47 & 0.67 & 0.33 \\
Hungary & 1.00 & 0.50 & 0.28 & 0.42 & 0.28 & 0.30 & 0.50 & 0.00 \\
Latvia & 1.00 & 1.00 & 0.38 & 0.57 & 0.29 & 0.40 & 0.67 & 0.67 \\
Lithuania & 1.00 & 1.00 & 0.51 & 0.75 & 0.26 & 0.75 & 0.33 & 0.00 \\
Palau & 1.00 & 1.00 & 0.64 & 0.73 & 0.64 & 0.73 & 1.00 & 0.67
\end{tabular}


Appendix A: Disclosure and enforcement indices by income groups

\begin{tabular}{|c|c|c|c|c|c|c|c|c|}
\hline \multirow[b]{2}{*}{ Country } & \multicolumn{2}{|c|}{$\begin{array}{l}\text { Requirements and } \\
\text { public availability }\end{array}$} & \multicolumn{4}{|c|}{ Form content (based on universal form concept) } & \multicolumn{2}{|c|}{ Enforcement } \\
\hline & $\begin{array}{l}\text { Dsclosure } \\
\text { required }\end{array}$ & $\begin{array}{l}\text { Publicly } \\
\text { available }\end{array}$ & $\begin{array}{c}\text { Values } \\
\text { available to } \\
\text { congress }\end{array}$ & $\begin{array}{c}\text { Sources } \\
\text { available to } \\
\text { congress }\end{array}$ & $\begin{array}{c}\text { Values } \\
\text { publicly } \\
\text { available }\end{array}$ & $\begin{array}{l}\text { Sources } \\
\text { publicly } \\
\text { available }\end{array}$ & $\begin{array}{l}\text { Registrar } \\
\text { strength }\end{array}$ & $\begin{array}{l}\text { Checking } \\
\text { unit strength }\end{array}$ \\
\hline Poland & 1.00 & 1.00 & 0.32 & 0.84 & 0.28 & 0.79 & 0.17 & 0.33 \\
\hline Romania & 1.00 & 1.00 & 0.60 & 0.79 & 0.60 & 0.79 & 0.67 & 1.00 \\
\hline Slovakia & 1.00 & 1.00 & 0.34 & 0.48 & 0.19 & 0.28 & 0.33 & 0.33 \\
\hline South Africa & 1.00 & 1.00 & 0.29 & 0.66 & 0.22 & 0.66 & 0.33 & 0.33 \\
\hline Mean & 1.00 & 0.96 & 0.43 & 0.63 & 0.38 & 0.58 & 0.46 & 0.36 \\
\hline
\end{tabular}

Panel E: Upper middle income with disclosures available to congress

\begin{tabular}{lll|lllllll} 
Belize & 1.00 & 0.00 & 0.44 & 0.38 & 0.00 & 0.00 & 1.00 & 0.67 \\
Costa Rica & 1.00 & 0.00 & 0.67 & 0.67 & 0.00 & 0.00 & 0.67 & 0.33 \\
Gabon & 1.00 & 0.00 & 0.29 & 0.45 & 0.00 & 0.00 & 1.00 & 0.67 \\
Lebanon & 1.00 & 0.00 & 0.10 & 0.06 & 0.00 & 0.00 & 0.67 & 0.33 \\
Mauritius & 1.00 & 0.00 & 0.15 & 0.03 & 0.00 & 0.00 & 0.67 & 0.33 \\
Mexico & 1.00 & 0.00 & 0.46 & 0.62 & 0.00 & 0.00 & 1.00 & 0.33 \\
Russia & 1.00 & 0.00 & 0.35 & 0.45 & 0.00 & 0.00 & 0.33 & 0.67 \\
St. Lucia & 1.00 & 0.00 & 0.67 & 0.67 & 0.00 & 0.00 & 1.00 & 1.00 \\
Trinidad and Tobago & 1.00 & 0.00 & 0.64 & 0.73 & 0.00 & 0.00 & 1.00 \\
Turkey & 1.00 & 0.00 & 0.31 & 0.38 & 0.00 & 0.00 & 0.33 & 0.67 \\
Uruguay & 1.00 & 0.00 & 0.46 & 0.49 & 0.00 & 0.00 & 1.00 & 0.33 \\
Venezuela & 1.00 & 0.00 & 0.37 & 0.38 & 0.00 & 0.00 & 0.67 & 0.67 \\
Mean & $\mathbf{1 . 0 0}$ & $\mathbf{0 . 0 0}$ & $\mathbf{0 . 4 1}$ & $\mathbf{0 . 4 4}$ & $\mathbf{0 . 0 0}$ & $\mathbf{0 . 0 0}$ & $\mathbf{0 . 7 8}$ \\
\hline
\end{tabular}

Panel F: Upper middle income without disclosure requirements

\begin{tabular}{lll|lllllll} 
Botswana & 0.00 & 0.00 & 0.00 & 0.00 & 0.00 & 0.00 & 0.00 & 0.00 \\
Malaysia & 0.00 & 0.00 & 0.00 & 0.00 & 0.00 & 0.00 & 0.00 & 0.00 \\
Oman & 0.00 & 0.00 & 0.00 & 0.00 & 0.00 & 0.00 & 0.00 & 0.00 \\
Panama & 0.00 & 0.00 & 0.00 & 0.00 & 0.00 & 0.00 & 0.00 & 0.00 \\
Seychelles & 0.00 & 0.00 & 0.00 & 0.00 & 0.00 & 0.00 & 0.00 & 0.00 \\
Mean & $\mathbf{0 . 0 0}$ & $\mathbf{0 . 0 0}$ & $\mathbf{0 . 0 0}$ & $\mathbf{0 . 0 0}$ & $\mathbf{0 . 0 0}$ & $\mathbf{0 . 0 0}$ & $\mathbf{0 . 0 0}$ & $\mathbf{0 . 0 0}$ \\
\hline
\end{tabular}

Panel G: Lower middle income with publicly available disclosures

\begin{tabular}{lll|lllll|lll} 
Albania & 1.00 & 1.00 & 0.64 & 0.77 & 0.48 & 0.60 & 0.67 & 0.67 \\
Armenia & 1.00 & 1.00 & 0.34 & 0.45 & 0.27 & 0.37 & 0.67 & 0.33 \\
Bolivia & 1.00 & 1.00 & 0.48 & 0.48 & 0.11 & 0.00 & 0.67 & 0.00 \\
Bulgaria & 1.00 & 1.00 & 0.50 & 0.33 & 0.50 & 0.33 & 1.00 & 0.67 \\
Colombia & 1.00 & 0.50 & 0.44 & 0.60 & 0.10 & 0.27 & 0.33 \\
Dominican Republic & 1.00 & 1.00 & 0.32 & 0.35 & 0.32 & 0.35 & 0.67 & 0.00 \\
Georgia & 1.00 & 1.00 & 0.71 & 0.70 & 0.71 & 0.70 & 0.67 & 0.33 \\
Indonesia & 1.00 & 1.00 & 0.73 & 0.68 & 0.22 & 0.18 & 1.00 & 0.33 \\
Macedonia & 1.00 & 1.00 & 0.55 & 0.49 & 0.49 & 0.35 & 0.67 \\
Moldova & 1.00 & 1.00 & 0.41 & 0.40 & 0.41 & 0.40 & 0.33 \\
Montenegro & 1.00 & 1.00 & 0.40 & 0.42 & 0.28 & 0.42 & 0.33 \\
Philippines & 1.00 & 1.00 & 0.21 & 0.34 & 0.21 & 0.34 & 0.33 & 0.00 \\
Thailand & 1.00 & 1.00 & 0.58 & 0.59 & 0.58 & 0.59 & 0.67 & 0.00 \\
Mean & $\mathbf{1 . 0 0}$ & $\mathbf{0 . 9 6}$ & $\mathbf{0 . 4 8}$ & $\mathbf{0 . 5 1}$ & $\mathbf{0 . 3 6}$ & $\mathbf{0 . 3 8}$ & $\mathbf{0 . 6 2}$ & 0.67 \\
\hline
\end{tabular}

Panel H: Lower middle income with disclosures available to congress

\begin{tabular}{lll|cccc|cc} 
Algeria & 1.00 & 0.00 & 0.06 & 0.21 & 0.00 & 0.00 & 0.67 & 0.33 \\
Angola & 1.00 & 0.00 &. &. & 0.00 & 0.00 & 0.33 & 0.00 \\
Belarus & 1.00 & 0.00 & 0.64 & 0.67 & 0.00 & 0.00 & 0.33 & 0.33 \\
Bhutan & 1.00 & 0.00 & 0.40 & 0.38 & 0.00 & 0.00 & 0.67 & 0.33 \\
Bosnia and Herzegovina & 1.00 & 0.00 & 0.31 & 0.42 & 0.00 & 0.00 & 0.33 & 0.33 \\
Brazil & 1.00 & 0.00 & 0.62 & 0.50 & 0.00 & 0.00 & 0.67 & 0.67 \\
Cape Verde & 1.00 & 0.00 & 0.26 & 0.51 & 0.00 & 0.00 & 0.67 & 0.33 \\
Ecuador & 1.00 & 0.00 & 0.36 & 0.38 & 0.00 & 0.00 & 0.67 & 0.33 \\
Egypt & 1.00 & 0.00 & 0.28 & 0.60 & 0.00 & 0.00 & 0.33 \\
El Salvador & 1.00 & 0.00 & 0.46 & 0.40 & 0.00 & 0.00 & 0.67 & 0.33 \\
Guatemala & 1.00 & 0.00 & 0.58 & 0.55 & 0.00 & 0.00 & 0.67 & 0.33
\end{tabular}


Appendix A: Disclosure and enforcement indices by income groups

\begin{tabular}{|c|c|c|c|c|c|c|c|c|}
\hline \multirow[b]{2}{*}{ Country } & \multicolumn{2}{|c|}{$\begin{array}{l}\text { Requirements and } \\
\text { public availability }\end{array}$} & \multicolumn{4}{|c|}{ Form content (based on universal form concept) } & \multicolumn{2}{|c|}{ Enforcement } \\
\hline & $\begin{array}{l}\text { Dsclosure } \\
\text { required }\end{array}$ & $\begin{array}{l}\text { Publicly } \\
\text { available }\end{array}$ & $\begin{array}{c}\text { Values } \\
\text { available to } \\
\text { congress }\end{array}$ & $\begin{array}{c}\text { Sources } \\
\text { available to } \\
\text { congress }\end{array}$ & $\begin{array}{c}\text { Values } \\
\text { publicly } \\
\text { available }\end{array}$ & $\begin{array}{l}\text { Sources } \\
\text { publicly } \\
\text { available }\end{array}$ & $\begin{array}{l}\text { Registrar } \\
\text { strength }\end{array}$ & $\begin{array}{c}\text { Checking } \\
\text { unit strength }\end{array}$ \\
\hline Guyana & 1.00 & 0.00 & 0.44 & 0.71 & 0.00 & 0.00 & 1.00 & 0.67 \\
\hline Honduras & 1.00 & 0.00 & 0.54 & 0.54 & 0.00 & 0.00 & 0.67 & 1.00 \\
\hline Jamaica & 1.00 & 0.00 & 0.67 & 0.50 & 0.00 & 0.00 & 0.67 & 0.67 \\
\hline Jordan & 1.00 & 0.00 & 0.17 & 0.21 & 0.00 & 0.00 & 0.67 & 0.67 \\
\hline Kazakhstan & 1.00 & 0.00 & 0.26 & 0.28 & 0.00 & 0.00 & 0.67 & 0.67 \\
\hline Morocco & 1.00 & 0.00 & . & . & 0.00 & 0.00 & 0.33 & 0.00 \\
\hline Namibia & 1.00 & 0.00 & 0.73 & 0.88 & 0.00 & 0.00 & 0.33 & 0.33 \\
\hline Nicaragua & 1.00 & 0.00 & 0.64 & 0.64 & 0.00 & 0.00 & 0.67 & 0.67 \\
\hline Paraguay & 1.00 & 0.00 & 0.56 & 0.47 & 0.00 & 0.00 & 0.33 & 0.33 \\
\hline Peru & 1.00 & 0.00 & 0.58 & 0.38 & 0.00 & 0.00 & 0.33 & 0.33 \\
\hline Serbia & 1.00 & 0.00 & 0.40 & 0.57 & 0.00 & 0.00 & 0.67 & 0.67 \\
\hline Sri Lanka & 1.00 & 0.00 & 0.22 & 0.40 & 0.00 & 0.00 & 0.33 & 0.33 \\
\hline Swaziland & 1.00 & 0.00 & . & . & 0.00 & 0.00 & 0.33 & 0.00 \\
\hline Ukraine & 1.00 & 0.00 & 0.27 & 0.16 & 0.00 & 0.00 & 0.33 & 0.33 \\
\hline Vanuatu & 1.00 & 0.00 & 0.22 & 0.14 & 0.00 & 0.00 & 0.67 & 0.33 \\
\hline Mean & 1.00 & 0.00 & 0.42 & 0.46 & 0.00 & 0.00 & 0.54 & 0.41 \\
\hline
\end{tabular}

Panel I: Lower middle income without disclosure requirements

\begin{tabular}{|c|c|c|c|c|c|c|c|c|}
\hline Azerbaijan & 0.00 & 0.00 & 0.00 & 0.00 & 0.00 & 0.00 & 0.00 & 0.00 \\
\hline Cameroon & 0.00 & 0.00 & 0.00 & 0.00 & 0.00 & 0.00 & 0.00 & 0.00 \\
\hline China & 0.00 & 0.00 & 0.00 & 0.00 & 0.00 & 0.00 & 0.00 & 0.00 \\
\hline Congo, Republic & 0.00 & 0.00 & 0.00 & 0.00 & 0.00 & 0.00 & 0.00 & 0.00 \\
\hline Djibouti & 0.00 & 0.00 & 0.00 & 0.00 & 0.00 & 0.00 & 0.00 & 0.00 \\
\hline Dominica & 0.00 & 0.00 & 0.00 & 0.00 & 0.00 & 0.00 & 0.00 & 0.00 \\
\hline Fiji & 0.00 & 0.00 & 0.00 & 0.00 & 0.00 & 0.00 & 0.00 & 0.00 \\
\hline Iran & 0.00 & 0.00 & 0.00 & 0.00 & 0.00 & 0.00 & 0.00 & 0.00 \\
\hline Iraq & 0.00 & 0.00 & 0.00 & 0.00 & 0.00 & 0.00 & 0.00 & 0.00 \\
\hline Kiribati & 0.00 & 0.00 & 0.00 & 0.00 & 0.00 & 0.00 & 0.00 & 0.00 \\
\hline Lesotho & 0.00 & 0.00 & 0.00 & 0.00 & 0.00 & 0.00 & 0.00 & 0.00 \\
\hline Maldives & 0.00 & 0.00 & 0.00 & 0.00 & 0.00 & 0.00 & 0.00 & 0.00 \\
\hline Micronesia & 0.00 & 0.00 & 0.00 & 0.00 & 0.00 & 0.00 & 0.00 & 0.00 \\
\hline St. Vincent \& Grenadines & 0.00 & 0.00 & 0.00 & 0.00 & 0.00 & 0.00 & 0.00 & 0.00 \\
\hline Suriname & 0.00 & 0.00 & 0.00 & 0.00 & 0.00 & 0.00 & 0.00 & 0.00 \\
\hline Syria & 0.00 & 0.00 & 0.00 & 0.00 & 0.00 & 0.00 & 0.00 & 0.00 \\
\hline Tonga & 0.00 & 0.00 & 0.00 & 0.00 & 0.00 & 0.00 & 0.00 & 0.00 \\
\hline Tunisia & 0.00 & 0.00 & 0.00 & 0.00 & 0.00 & 0.00 & 0.00 & 0.00 \\
\hline West Bank and Gaza & 0.00 & 0.00 & 0.00 & 0.00 & 0.00 & 0.00 & 0.00 & 0.00 \\
\hline Western Samoa & 0.00 & 0.00 & 0.00 & 0.00 & 0.00 & 0.00 & 0.00 & 0.00 \\
\hline Mean & 0.00 & 0.00 & 0.00 & 0.00 & 0.00 & 0.00 & 0.00 & 0.00 \\
\hline
\end{tabular}

Panel J: Low income with publicly available disclosures

\begin{tabular}{|c|c|c|c|c|c|c|c|c|}
\hline Kyrgyz Republic & 1.00 & 1.00 & 0.63 & 0.67 & 0.44 & 0.31 & 0.67 & 0.67 \\
\hline Mongolia & 1.00 & 1.00 & 0.62 & 0.64 & 0.62 & 0.64 & 1.00 & 0.33 \\
\hline Pakistan & 1.00 & 1.00 & 0.25 & 0.21 & 0.25 & 0.21 & 1.00 & 0.33 \\
\hline Zambia & 0.00 & 1.00 & 0.00 & 0.00 & 0.56 & 0.50 & 0.33 & 0.00 \\
\hline Mean & 0.75 & 1.00 & 0.38 & 0.38 & 0.47 & 0.42 & 0.75 & 0.33 \\
\hline
\end{tabular}

Panel K: Low income with disclosures available to congress

\begin{tabular}{lcc|ccccc|c} 
Comoros & 1.00 & 0.00 &. &. & 0.00 & 0.00 & 0.00 & 0.00 \\
Ghana & 1.00 & 0.00 & 0.48 & 0.56 & 0.00 & 0.00 & 0.33 & 0.33 \\
India & 1.00 & 0.00 & 0.33 & 0.38 & 0.00 & 0.00 & 0.00 & 0.00 \\
Kenya & 1.00 & 0.00 & 0.42 & 0.21 & 0.00 & 0.00 & 0.33 & 0.00 \\
Madagascar & 1.00 & 0.00 & 0.33 & 0.38 & 0.00 & 0.00 & 0.67 & 0.67 \\
Nigeria & 1.00 & 0.00 & 0.55 & 0.55 & 0.00 & 0.00 & 0.67 & 0.33 \\
Papua New Guinea & 1.00 & 0.00 &. &. & 0.00 & 0.00 & 0.67 & 0.67 \\
Rwanda & 1.00 & 0.00 & 0.33 & 0.38 & 0.00 & 0.00 & 0.33 & 0.00 \\
Sao Tome and Principe & 1.00 & 0.00 &. &. & 0.00 & 0.00 & 0.00 & 0.00 \\
Solomon Island & 1.00 & 0.00 &. &. & 0.00 & 0.00 & 0.67 & 0.33 \\
Tanzania & 1.00 & 0.00 & 0.51 & 0.55 & 0.00 & 0.00 & 0.67 & 0.33 \\
Togo & 1.00 & 0.00 &. &. & 0.00 & 0.00 & 0.00 & 0.00
\end{tabular}


Appendix A: Disclosure and enforcement indices by income groups

\begin{tabular}{|c|c|c|c|c|c|c|c|c|}
\hline \multirow[b]{2}{*}{ Country } & \multicolumn{2}{|c|}{$\begin{array}{l}\text { Requirements and } \\
\text { public availability }\end{array}$} & \multicolumn{4}{|c|}{ Form content (based on universal form concept) } & \multicolumn{2}{|c|}{ Enforcement } \\
\hline & $\begin{array}{l}\text { Dsclosure } \\
\text { required }\end{array}$ & $\begin{array}{l}\text { Publicly } \\
\text { available }\end{array}$ & $\begin{array}{c}\text { Values } \\
\text { available to } \\
\text { congress }\end{array}$ & $\begin{array}{c}\text { Sources } \\
\text { available to } \\
\text { congress }\end{array}$ & $\begin{array}{c}\text { Values } \\
\text { publicly } \\
\text { available }\end{array}$ & $\begin{array}{c}\text { Sources } \\
\text { publicly } \\
\text { available }\end{array}$ & $\begin{array}{l}\text { Registrar } \\
\text { strength }\end{array}$ & $\begin{array}{l}\text { Checking } \\
\text { unit strength }\end{array}$ \\
\hline Uganda & 1.00 & 0.00 & 0.50 & 0.59 & 0.00 & 0.00 & 0.67 & 0.33 \\
\hline Vietnam & 1.00 & 0.00 & 0.09 & 0.21 & 0.00 & 0.00 & 0.00 & 0.00 \\
\hline \multirow[t]{2}{*}{ Mean } & 1.00 & $\mathbf{0 . 0 0}$ & 0.39 & $\mathbf{0 . 4 2}$ & $\mathbf{0 . 0 0}$ & $\mathbf{0 . 0 0}$ & 0.36 & 0.21 \\
\hline & \multicolumn{8}{|c|}{ Panel L: Low income without disclosure requirements } \\
\hline Afghanistan & 0.00 & 0.00 & 0.00 & 0.00 & 0.00 & 0.00 & 0.00 & 0.00 \\
\hline Bangladesh & 0.00 & 0.00 & 0.00 & 0.00 & 0.00 & 0.00 & 0.00 & 0.00 \\
\hline Benin & 0.00 & 0.00 & 0.00 & 0.00 & 0.00 & 0.00 & 0.00 & 0.00 \\
\hline Burkina Faso & 0.00 & 0.00 & 0.00 & 0.00 & 0.00 & 0.00 & 0.00 & 0.00 \\
\hline Burundi & 0.00 & 0.00 & 0.00 & 0.00 & 0.00 & 0.00 & 0.00 & 0.00 \\
\hline Cambodia & 0.00 & 0.00 & 0.00 & 0.00 & 0.00 & 0.00 & 0.00 & 0.00 \\
\hline Central African Republic & 0.00 & 0.00 & 0.00 & 0.00 & 0.00 & 0.00 & 0.00 & 0.00 \\
\hline Chad & 0.00 & 0.00 & 0.00 & 0.00 & 0.00 & 0.00 & 0.00 & 0.00 \\
\hline Congo, Democratic Republic & 0.00 & 0.00 & 0.00 & 0.00 & 0.00 & 0.00 & 0.00 & 0.00 \\
\hline Côte d'Ivoire & 0.00 & 0.00 & 0.00 & 0.00 & 0.00 & 0.00 & 0.00 & 0.00 \\
\hline Eritrea & 0.00 & 0.00 & 0.00 & 0.00 & 0.00 & 0.00 & 0.00 & 0.00 \\
\hline Ethiopia & 0.00 & 0.00 & 0.00 & 0.00 & 0.00 & 0.00 & 0.00 & 0.00 \\
\hline Gambia & 0.00 & 0.00 & 0.00 & 0.00 & 0.00 & 0.00 & 0.00 & 0.00 \\
\hline Guinea-Bissau & 0.00 & 0.00 & 0.00 & 0.00 & 0.00 & 0.00 & 0.67 & 0.33 \\
\hline Guinea & 0.00 & 0.00 & 0.00 & 0.00 & 0.00 & 0.00 & 0.00 & 0.00 \\
\hline Haiti & 0.00 & 0.00 & 0.00 & 0.00 & 0.00 & 0.00 & 0.00 & 0.00 \\
\hline Lao, People's Dem. Rep. & 0.00 & 0.00 & 0.00 & 0.00 & 0.00 & 0.00 & 0.00 & 0.00 \\
\hline Liberia & 0.00 & 0.00 & 0.00 & 0.00 & 0.00 & 0.00 & 0.00 & 0.00 \\
\hline Malawi & 0.00 & 0.00 & 0.00 & 0.00 & 0.00 & 0.00 & 0.00 & 0.00 \\
\hline Mali & 0.00 & 0.00 & 0.00 & 0.00 & 0.00 & 0.00 & 0.00 & 0.00 \\
\hline Mauritania & 0.00 & 0.00 & 0.00 & 0.00 & 0.00 & 0.00 & 0.00 & 0.00 \\
\hline Mozambique & 0.00 & 0.00 & 0.00 & 0.00 & 0.00 & 0.00 & 0.00 & 0.00 \\
\hline Niger & 0.00 & 0.00 & 0.00 & 0.00 & 0.00 & 0.00 & 0.00 & 0.00 \\
\hline Senegal & 0.00 & 0.00 & 0.00 & 0.00 & 0.00 & 0.00 & 0.00 & 0.00 \\
\hline Sierra Leone & 0.00 & 0.00 & 0.00 & 0.00 & 0.00 & 0.00 & 0.00 & 0.00 \\
\hline Sudan & 0.00 & 0.00 & 0.00 & 0.00 & 0.00 & 0.00 & 0.00 & 0.00 \\
\hline Tajikistan & 0.00 & 0.00 & 0.00 & 0.00 & 0.00 & 0.00 & 0.00 & 0.00 \\
\hline Timor-Leste & 0.00 & 0.00 & 0.00 & 0.00 & 0.00 & 0.00 & 0.00 & 0.00 \\
\hline Uzbekistan & 0.00 & 0.00 & 0.00 & 0.00 & 0.00 & 0.00 & 0.00 & 0.00 \\
\hline Yemen, Rep. & 0.00 & 0.00 & 0.00 & 0.00 & 0.00 & 0.00 & 0.00 & 0.00 \\
\hline Zimbabwe & 0.00 & 0.00 & 0.00 & 0.00 & 0.00 & 0.00 & 0.00 & 0.00 \\
\hline Mean & 0.00 & 0.00 & 0.00 & 0.00 & 0.00 & 0.00 & 0.02 & 0.01 \\
\hline
\end{tabular}

Note: As reported in the text, there are 8 countries where we could not obtain the blank form (see text for details). These countries have a "." in the diclosures of values and sources for congress. In all cases, these countries do not make the disclosures publicly available. 